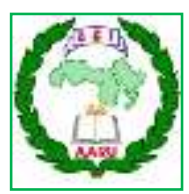

Arab Univ. J. Agric. Sci., Ain Shams Univ., Cairo, Egypt

28(4), 1203-1223, 2020

Website: http://ajs.journals.ekb.eg

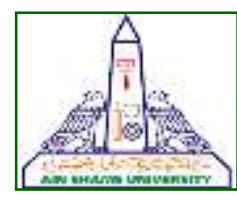

1203

\title{
Application of Methyl Jasmonate and Chitosan on Behavior of "Anna" Apple Seedlings Grown under Water and Heat Stress Conditions
}

[86]

\author{
Samah I Nasr ${ }^{1^{*}}$, Ghada M Soliman ${ }^{2}$ \\ 1- Higher Institute for Agriculture Co-Operation, P.O. Box. 198, Hadayek Shoubra, Cairo, Egypt. \\ 2- Horticulture Research Institute, Agriculture Research Centre, Giza, Egypt.
}

*Corresponding author: Samah55adel@yahoo.com

Received 14 October, 2020

Accepted 4 November, 2020

\begin{abstract}
The role of methyl jasmonate and chitosan application as anti- stress materials on responses of "Anna" apple seedlings grown under water and heat stresses was evaluated during 2018 and 2019 seasons. Anna" apple seedling were exposed to three levels of water regiem reated to avaialable $(100,80$ and $60 \%$ ), kept in the plastic greenhouse conditions at $45 \pm 2{ }^{\circ} \mathrm{C}$., and treated with MeJA at 1.0 and 2.0 $\mathrm{mM}$ as well as chitosan at 0.5 and $1.0 \%$. Vegetative growth parameters, leaf mineral contents, chemical constituents and physiological attributes were detcrmined through out the development of apple seedling abiotic stress. Vegetative growth parameters including plant height $(\mathrm{cm})$, average stem diameters $(\mathrm{cm})$, total number of leaves/ plant, leaf area $\left(\mathrm{cm}^{2}\right)$, number of branches/plant and shoot lengths (cm), fresh and dry weights (g/plant) greatly affected with both studied factors. Application of methyl jasmonate at $2.0 \mathrm{mM}$ and chitosan at $1.0 \%$ combined with irrigation with the three levels of recommended water regien (100, 80 and $60 \%$ ), were superior than other treatments or untreated one in recording the highest values of all vegetative growth parameters in both seasons. All anti-stress materials were effective in increasing apple seedlings levels of macro (N, P and K) and micro ( Fe, Zn, Mn and $\mathrm{Cu}$ ) elements compared to untreated apple seedlings. However, chitosan treatment at $1.0 \%$ in combination with all water regiems were more effective in improving the nutrition status of treated seedlings. Additionally, high values of total chlorophyll and carbohydrates were achieved by apple seedlings irrigated with $100 \%$ of water regiem and sprayed with higher concentration from chitosan or methyl jasmonate materials. On the other hand, the untreated seedlings under all irrigation water regiems
\end{abstract}

recorded the least values in this respect. On the contrary, the treatments of $2.0 \mathrm{mM}$ methyl jasmonate and $1.0 \%$ chitosan under heat and water stress conditions were effective in reducing proline amino acid, glycine betaine and phenolic compounds contents values which is similar to the apple seedling did not expose to stresses. Generally, it could be concluded that spraying apple seedlings with methyl jasmonate at $2.0 \mathrm{mM}$ and chitosan at $1.0 \%$ in combination with all water regiem considered a good horticulture application to alleviation of a biotic stress (water and heat).

Keywords: Apple seedlings, Methyl jasmonate, Chitosan, Biotic stress, Proline, Phenolic compounds

\section{Introduction}

The apple (Malus domestica Borkh.) is native to South East Asia, it is one of the most paramount and broadly grown fruit plants in the temperate zone in the world. Apple the most popular and favorite deciduous fruit cultivated in Egypt. "Anna" cultivar the most essential and preferred apple cultivars Egypt. The past few years, the cultivated area of "Anna" apple mounted rapidly in reclaimed lands. The rootstock has possibility to have an influence on the properties of scion (growth, productivity, fruit quality in addition to resistance to all type of stress). The rootstock has the ability to tolerate partial or completely drought is the best part for budding as, the amount of water transferred from the roots to the buds is controlled through the xylem vessels (Wang et al 2012).

To increase production and high fruit quality for deciduous fruit trees, the irrigation water should be managed. But in many regions of the world water 
resources may not be sufficient to achieve maximum yield and higher reverting. For these reasons, these problems may worsen in the future; where water resources are becoming limited worldwide and will not be sufficient to meet the population increase (Postel 1998). Reduction irrigation water due to high competition from users (Fereres and Evans 2006), and around the world where agricultural irrigation consumes at least $85 \%$ of all water used (Jury and Vaux 2007). Therefore, it is necessary to study the consequences of water scarcity in deciduous fruit trees and work to solve those using techniques that limit this scarcity (Mikhael and Mady 2007).

The deficit of organized irrigation is considered an essential technique of saving water and its methods have been evolved to enhance control of vegetative growth in high-density orchards in order to acquire the optimal productivity and rise fruit quality. Generally, deficit of regular irrigation is applied through a period of slow fruit growth. Hence, it's far useful for decreasing rapid vegetative growth and loss of nutrients during leaching in addition to the availability of irrigation water (Soliman et al 2018). A major problem in many arid and semi-arid regions is water stress, as Egypt, where plants are exposure to prolonged or less to water deficit (Boyer 1982). Also, can be described as the ratio between the amount of water required for plant growth and the water available in its environment, (Fang and Xiong 2015).

Water stress lowers the potential of the plant due to the trouble of its physiological activity resulting from the lack of water consumption (Budak et al 2013). In general, drought stress acts to destroy and degrade chloroplasts and reduce the chlorophyll content and enzyme activity in the Calvin cycle during photosynthesis (Monakhova and Chernyader 2002). Likewise, Mafakheri et al (2010) reported decreased leaf chlorophyll content due to drought-induced stress. Intervention with the cellular metabolism of the plant is correlatied with the decomposition of proteins (Sakata et al 2014). In another study, Farouk and Ramadan (2012) believe that plants go along with the drought in dry circumstance toward different ways such as closing the stomata, osmotic regulation and the accumulation of compatible soluble materials with dryness. Proline as an osmotic regulator plays a major role in maintaining water balance, protein stability, stabilizing membranes also the protein synthesis system, providing carbon and nitrogen storage for growth after reducing stress and relief the risk of production of reactive oxygen species (Bllinger and Larer 1987, Verbruggen and Hermans 2008). Soluble polysaccharides play as an osmotic regulator, cell membrane stabilizers, and a control device for cellular swellings. Also, plants with a high value of soluble sugar can efficiently respond to drought stress through osmotic modification (Slama et al 2007).

Global warming resulting from the high concentration of carbon dioxide in the atmosphere in combination with other greenhouse gases is endangering agriculture and other industries that use the natural environment (IPCC 2001). High temperature is one of the main environmental factors affecting plant growth and productivity (Havaux 1993). Exposure of plants to changing temperatures has a profound effect on plant metabolism (Chaitanya and Sundar 2001). Also, high temperature stress reasons a few physiological, biochemical and molecular modifications in plant metabolism which includes protein denaturation, lipid liquefaction and derangement of membrane integrity (Levitt 1980). However, Tsuchida et al (2011) confirmed that heat stress prevent growth and carbohydrate accumulation, many of the modifications that appear through acclimation to heat stress are reversible, but if the stress is too severe, changes are irreversible and may even lead to death. The stress induced by high temperature influence the internal anatomy at the tissue and cell level as well as the subcellular level. All these changes under heat stress cause decrease plant growth and productivity. Glycine betaine (GB) is activated under several biotic stress which acts as a good solvent in plants in such stressful situations (Sakamoto and Murata 2002). Under stress conditions, glycine betaine production capacity varies from species plant (Ashraf and Foolad 2007, Naz et al 2018).

Chitosan is a natural polymer resulted from of chitin, which has great capacity in action exchange in acid solutions and has great resemblance with metallic ions (Ravi Kumar 2000), which is the 2nd most plenteous polysaccharide found in nature after cellulose.Chitosan has been visible as non-dangerous biodegradable, (Itoh et al 2013). In agriculture has been proven to stimulate growth and activate the protection mechanisms in plants (Rinaudo 2006). Chitosan is protection responses correlated to various types of stresses (biotic and abiotic).

Chitosan application has an extensive prospect that could address the issues regarding stress adaptation. Several research of chitosan mechanism below biotic stress were reviewed (Sharif et al 2018). Chitosan and its oligomers were used as abiotic stresses like, water deficit, salinity and heat stress (Malerba and Cerana 2015). Chitosan lessen 


\section{Application of methyl jasmonate and chitosan on behavior of "Anna"}

apple seedlings grown under water and heat stress conditions

drought stress and encourage, growth through decreasing the damaging unfastened radicals accumulation through activating antioxidants and enzymes (Malekpoor et al 2016). Also, chitosan in acts as jasmonic acid in regulating water use through affecting on stomata aperture (Farouk and Ramadan 2012).

Jasmonic acid (3-oxo-2-20-cis-pentenyl-cyclopentane-1-acetic acid, abbreviated as JA) is a growth-regulating substance which discovered in plant. Jasmonates (JAs) inclusive JA and its chemical analogous classed as fatty acids and recognized as a stress-related hormone that modify essential growth and developmental processes (Wasternack and Hause 2013). Jasmonates play an essential role in defense mechanisms through protecting plants from biotic and abiotic stresses (Cheong and Choi 2003). Generally, Jasmonates control responses by modifying plant growth and development through far-reaching cues (Huber et al 2005, Motallebi et al 2015). Also, regulate secondary plant metabolism, either by stimulating the production of toxic compounds. (Moreira et al 2012) or by rising the activity and concentration reactive oxygen species to protect against abiotic stresses (Anjum et al 2011), consequently increasing the rate of recovery from damage (Cao et al 2009). Jasmonates can stimulate stomata opening, prevent Rubisco biosynthesis, and affect nitrogen and phosphorous uptake and transport of organic matter such as glucosen particular, as a signaling molecule, JAs can efficaciously mediate responses towards environmental stresses through inducing a sequence of genes expression. (Campos et al 2014) Jasmonic acid induces a resistance gene associated with plant resistance as a Campos response to external damage (mechanical damage, herbivores, and insects) and pathogen infection, (Gupta et al 2017).

The target of this research was to evaluate the effect of methyl jasmonate and chitosan applications on vegetative growth, mineral contents as well as Physio-biochemical responses of Anna apple seedlings growing under water and heat stresses.

\section{Material and Methods}

The present work was carried out during the two successive seasons 2018 and 2019 in order to study the effect of Methyl Jasmonate and Chitosan application as anti-water and heat stress materials on vegetative growth and chemical constituents, of "Anna" apple seedling grafted on MM 106 rootstock. The seedlings chosen for this study were uniform size and healthy, one -year-old, transplanted in midJanuary in each season in plastic pots of $45 \times 30$ $\mathrm{cm}$ (diameter $\times$ height) and filled with a soil mixture consisting of sand, silt and peat moss (1:1:1), each pots was used for one plant. The experiment include two factors (three levels of water stress) and (five treatments of anti-stress materials plus control treatments).

Regarding water stress factor, "Anna" apple seedlings were selected and divided into three levels of water stress:

1. The first level. $100 \%$ of supplement water, like practice by the local nurseries farmers in the studied region (8000 seedlings/fed Irrigated with water at rate of $5000 \mathrm{m3} / \mathrm{fed} / \mathrm{year}$ the plants irrigated three times weekly during the growing season from March to September and once a week during dormancy period. The amount of added water each time was estimated 5.78 liter / seedling (625 liter / seedling / year).

2. The second level, moderate water stress $(80 \%$ of supplement water, $4000 \mathrm{~m} 3 / \mathrm{fed} / \mathrm{year}$ ) .The amount of added water each time was estimated 4.63 liter / seedling (500 liter / seedling / year).

3 . The third level, severe water stress $(60 \%$ of supplement water $3000 \mathrm{~m} 3 / \mathrm{fed} / \mathrm{year}$,). The amount of added water each time was estimated 3.47 liter / seedling (375 liter / seedling / year).

Regarding anti-stress materiels, each level of water stress Included 6 anti-stress treatments of Methyl Jasmonate and Chitosan (0.0, $1.0 \mathrm{mM}$ and 2.0 $\mathrm{mM}$ MeJA \& $0.5 \%$ and $1.0 \%$ Chitosan) conducted in the plastic greenhouse conditions at $45 \pm 2^{\circ} \mathrm{C}$. While, control plants were kept in the Usual greenhouse during the experiment to expose to the water stress only.

Spraying of Methyl Jasmonate and Chitosan were carried out at 15th May and repeated on the same seedling in mid-June in both studied seasons. A split plot design in 4 replicates was followed as experimental design, water steers levels put in the main plot and anti-stress materiels spraying arranged in sub - main plot. Consequently, the selected seedlings were divided to eighteen treatments, as follows:

$1.100 \%$ of supplement water plus spraying of MeJA at $1.0 \mathrm{mM}$.

2. $100 \%$ of supplement water plus spraying of MeJA at $2.0 \mathrm{mM}$.

3. $100 \%$ of supplement water plus spraying of Chitosan at $0.5 \%$.

4. $100 \%$ of supplement water plus spraying of Chitosan at $0.5 \%$. 
5. $100 \%$ of supplement water without any spraying (untreated). The treatments $1-5$ perform in plastic greenhouse conditions at $45 \pm 2{ }^{\circ} \mathrm{C}$.

6. $100 \%$ of supplement water without any spraying and perform in the wooden greenhouse (no stress water and heat, named control).

The same previous treatments were applied at the two other levels of water stress ( 80 and $60 \%$ water stress). Thus 3 levels of water stress $\times 6$ treatments of anti-stress material $\times 4$ replicates $=72$ seedlings for each season. The following measurements were recorded:

\subsection{Vegetative growth parameters}

Plant height $(\mathrm{cm})$, average stem diameters $(\mathrm{cm})$, average number of leaves/ seedling, average leaf area $\left(\mathrm{cm}^{2}\right)$, number of branches/ seedling and shoot lengths $(\mathrm{cm})$, were measured both at the beginning of stress treatments (mid-May) as initial reading and the end of each growing season (mid Nov.). However, at the end of growing season (mid Nov of each season), whole seedlings of Anna apple were uprooted and cleaned with tap water and fresh and dry weights $(\mathrm{g})$ were weighted.

\subsection{Leaf mineral contents}

Samples of thirty leaves from the middle part of shoots were selected at random from each replicate after three months of stress application (mid -August). The leaves were washed, dried at $70^{\circ} \mathrm{C}$ till constant weight, grind and digested according to (Rebbeca 2004).

\section{$2.3 \mathrm{~N}, \mathrm{P}, \mathrm{K}, \mathrm{Ca}$ and $\mathrm{Mg} \%$}

Total nitrogen was determined as percentage using the micro-Kjeldahl method as described by Wilde et al (1985)

Potassium content was determined by Flame photometer as percentage according to method of Jackson (1976).

Phosphorus content: was estimated as percentage the method described by Bringham (1982)

Magnesium (Mg) and Calcium (Ca contents): were determined using an atomicab sorption spectrophotometer Chapman and Pratt (1982).

$\mathrm{Fe}, \mathrm{Zn}, \mathrm{Cu}$ and $\mathrm{Mn}$ (ppm): were determined in digested solutions and measured using an absorption spectrophotometer according to Chapman and Pratt (1982).

Chemical constituents: Total chlorophyll (mg/100 $\mathrm{g}$ fresh weight) was determined according to Moran and Porath (1985). Total carbohydrates content was determined in dried shoot powder as percentage according to Smith et al (1979).

\subsection{Physiological attributes}

Proline amino acid content ( $\mu \mathrm{g} / \mathrm{g}$ dry weight) was measured of the leaves according to Bates et al (1973).

Glycine bectaine content ( $\mu \mathrm{g} / \mathrm{g}$ dry weight) was determined of the leaves according to Camilo et al (2019).

Phenolic content ( $\mathrm{mg} / 100 \mathrm{~g}$ fresh weight) was determined the leaves according to Singleton and Rossi (1965).

Statistical analysis: Data that obtained during 2018 and 2019 were subjected to analysis of variance method according to Snedecor and Cochran (1990) to assess the program effects. Duncan's Multiple Range tested (Duncan 1955) were used to compare differences among means.

\section{Results and Discussion}

\subsection{Vegetative growth parameters}

\subsubsection{Plant height $(\mathrm{cm})$ and average stem diame- ter $(\mathrm{cm})$}

Data in Table 1 show the effect of methyl jasmonate and Chitosan application in combination with water and heat stresses conditions on plant height $(\mathrm{cm})$ and average stem diameter $(\mathrm{cm})$ of "Anna" apple seedlings during 2018 and 2019 seasons.

\subsubsection{Plant height $(\mathrm{cm})$}

A decline in plant height had Happened due to water stress effect due to response to water stress in both seasons, the highest plant values were recorded with $100 \%$ of recommended water $(119.6 \mathrm{~cm}$ for the 1st season and $131.1 \mathrm{~cm}$ for the 2nd one), while $60 \%$ of recommended water gave the lowest value ( 100.9 and $107.1 \mathrm{~cm}$ for both seasons) . However, plant height were superior in all treatments than untreated ones and the great effect was recorded by MeJA $2.0 \mathrm{mM}$ in both seasons $(117.3 \mathrm{~cm}$ for 2018 and $126.8 \mathrm{~cm}$ for 2019). However, the untreated seedlings were recorded the Least values of plant highest $(97.8$ and $105.3 \mathrm{~cm}$ ) for 2018 and 2019 seasons respectively. Interaction values showed that, the apple seedlings irrigated with $100 \%$ recommended water and sprayed with MeJA $2.0 \mathrm{mM}$ recorded the highest plant height values $(131.5 \mathrm{~cm}$ in 2018 and $141.3 \mathrm{~cm}$ in 2019), the same finding was also found with chitosan at $1.0 \%$ application $(127.4 \mathrm{~cm}$ in 2018 and $134.9 \mathrm{~cm}$ in 2019) with slightly differences between them. On the contrary, 
the least interaction values of plant height ( 94.8 and $98.3 \mathrm{~cm}$ for both seasons) were obtained with untreated seedlings irrigated with $60 \%$ of recommended dose of irrigation water.

\subsubsection{Average stem diameter $(\mathrm{cm})$}

A great effect to both studied factors on increasing average stem diameter of apple seedling was recorded in Table 1. It is clear that, the highest significant values stem diameter was found with $100 \%$ of recommended water $\left(1.51 \mathrm{~cm}\right.$ in the $1^{\text {st }}$ season and $1.60 \mathrm{~cm}$ in the $2^{\text {nd }}$ season), whereas $60 \%$ of recommended water recorded the lowest significant values in both seasons (1.11\&1.17 in 2018 \& 2019 respectively).

The highest significant value of average stem diameter due to applied treatments was obtained by MeJA $2.0 \mathrm{mM}(1.39 \mathrm{~cm}$ for the $1 \mathrm{st}$ season and $1.46 \mathrm{~cm}$ for the $2^{\text {nd }}$ one). As well as the apple seedlings treated with $1.0 \%$ chitosan $\left(1.33 \mathrm{~cm}\right.$ for the $1^{\text {st }}$ season) or control (1.35\&1.42 for both seasons respectively) exhibited the higher values of stem diameter. While the lowest significant values were recorded with untreated seedling in both seasons (1.12 and $1.23 \mathrm{~cm}$ respectively). In addition, other values were in between the abovementioned two favorites treatments.

Interaction effect to both factors showed that, seedlings exhibited the highest significant values under $100 \%$ of recommended water with MeJA 2.0 $\mathrm{mM}\left(1.62 \mathrm{~cm}\right.$ in the $1^{\text {st }}$ season and $1.71 \mathrm{~cm}$ in the $2^{\text {nd }}$ one) as well as $1 \%$ chitosan ( $1.56 \mathrm{~cm}$ for 2018 season and $1.63 \mathrm{~cm}$ for 2019 season). These treatments were considered the preferable, where their effect was equal to non-stressful plants (1.53 and $1.67 \mathrm{~cm}$ ) for 2018 and 2019 seasons respectively. On the contrary, untreated seedlings irrigated with recommended water quantity of $60 \%$ gave the lowest values of stem diameter $(0.95$ and $1.03 \mathrm{~cm})$ in season one and two respectively.

Chitosan stimulates plant growth and development as reduces water loss by transpiration (Young et al 2005). Spraying plants with chitosan in this respect, the existence of stomata closure was demonstrated, indicating that the stimulatory effect of growth, after stomata closure could be related to an antipruritic effect on the ground (Bittelli et al 2001). Conversely, jasmonic acid (JA) and its methyl ester, methyl jasmonate, an essential role in plant growth, development and response to environmental stresses. (Saniewski et al 2003).

Table 1. Effect of methyl jasmonate and chitosan application on plant height $(\mathrm{cm})$ and average stem diameter $(\mathrm{cm})$ of "Anna" apple seedlings grown under water and heat stress conditions during 2018 and 2019 seasons

\begin{tabular}{|c|c|c|c|c|c|c|c|c|}
\hline \multirow{3}{*}{ Treatments } & \multicolumn{4}{|c|}{ Plant height $(\mathrm{cm})$} & \multicolumn{4}{|c|}{ Average stem diameter (cm) } \\
\hline & \multicolumn{3}{|c|}{ Recommended water regiem } & \multirow{2}{*}{ Mean } & \multicolumn{3}{|c|}{ Recommended water regiem } & \multirow{2}{*}{ Mean } \\
\hline & $100 \%$ & $80 \%$ & $60 \%$ & & $100 \%$ & $80 \%$ & $60 \%$ & \\
\hline \multicolumn{9}{|c|}{ First Season } \\
\hline MeJA $1.0 \mathrm{mM}$ & $120.2 \mathrm{c}$ & 106.3 ef & $97.1 \mathrm{hi}$ & $107.9 \mathrm{C}$ & $1.51 \mathrm{~b}$ & $1.24 \mathrm{de}$ & $1.12 \mathrm{fg}$ & $1.29 \mathrm{BC}$ \\
\hline MeJA $2.0 \mathrm{mM}$ & $131.5 \mathrm{a}$ & $114.7 \mathrm{~d}$ & $105.7 \mathrm{fg}$ & $117.3 \mathrm{~A}$ & $1.62 \mathrm{a}$ & $1.37 \mathrm{c}$ & $1.17 \mathrm{e}-\mathrm{f}$ & $1.39 \mathrm{~A}$ \\
\hline Chitosan $0.5 \%$ & $112.8 \mathrm{~d}$ & $104.2 \mathrm{fg}$ & $96.4 \mathrm{hi}$ & $104.5 \mathrm{D}$ & $1.48 \mathrm{~b}$ & $1.22 \mathrm{de}$ & $1.08 \mathrm{~g}$ & $1.26 \mathrm{C}$ \\
\hline Chitosan $1.0 \%$ & $127.4 a b$ & $109.5 \mathrm{de}$ & $103.9 \mathrm{fg}$ & $113.6 \mathrm{~B}$ & $1.56 a b$ & $1.29 \mathrm{~cd}$ & 1.14 e-f & $1.33 \mathrm{~A}$ \\
\hline Untreated & $101.2 \mathrm{gh}$ & $97.3 \mathrm{hi}$ & $94.8 \mathrm{i}$ & $97.8 \mathrm{E}$ & $1.33 \mathrm{c}$ & $1.09 \mathrm{fg}$ & $0.95 \mathrm{~h}$ & $1.12 \mathrm{D}$ \\
\hline Control & $122.6 \mathrm{bc}$ & $111.2 \mathrm{de}$ & 107.2 ef & $113.7 \mathrm{~B}$ & $1.53 \mathrm{ab}$ & $1.33 \mathrm{c}$ & $1.19 \mathrm{~d}-\mathrm{f}$ & $1.35 \mathrm{AB}$ \\
\hline Mean & $119.6 \mathrm{~A}$ & $107.4 \mathrm{~B}$ & $100.9 \mathrm{C}$ & & $1.51 \mathrm{~A}$ & $1.26 \mathrm{~B}$ & $1.11 \mathrm{C}$ & \\
\hline \multicolumn{9}{|c|}{ Second Season } \\
\hline MeJA $1.0 \mathrm{mM}$ & $132.8 b$ & $113.8 \mathrm{f}$ & $104.4 \mathrm{hi}$ & $117.0 \mathrm{C}$ & $1.60 \mathrm{bc}$ & $1.30 \mathrm{fg}$ & $1.18 \mathrm{hi}$ & $1.36 \mathrm{BC}$ \\
\hline MeJA $2.0 \mathrm{mM}$ & $141.3 \mathrm{a}$ & $124.1 \mathrm{~cd}$ & 115.1 ef & $126.8 \mathrm{~A}$ & $1.71 \mathrm{a}$ & $1.42 \mathrm{e}$ & $1.25 \mathrm{gh}$ & $1.46 \mathrm{~A}$ \\
\hline Chitosan $0.5 \%$ & $127.7 \mathrm{c}$ & $110.4 \mathrm{fg}$ & $102.2 \mathrm{ij}$ & $113.4 \mathrm{D}$ & $1.54 \mathrm{~cd}$ & $1.26 \mathrm{f}-\mathrm{g}$ & $1.14 \mathrm{i}$ & $1.31 \mathrm{C}$ \\
\hline Chitosan $1.0 \%$ & $134.9 b$ & $119.5 \mathrm{de}$ & $108.6 \mathrm{gh}$ & $121.0 \mathrm{~B}$ & 1.63ab & 1.34 ef & $1.19 \mathrm{hi}$ & $1.39 \mathrm{~B}$ \\
\hline Untreated & $113.2 \mathrm{fg}$ & $104.5 \mathrm{hi}$ & $98.3 \mathrm{j}$ & 105.3 E & $1.45 \mathrm{de}$ & $1.20 \mathrm{~g}-\mathrm{i}$ & 1.03 j & $1.23 \mathrm{D}$ \\
\hline Control & $136.7 \mathrm{ab}$ & $120.1 \mathrm{~d}$ & $113.8 \mathrm{f}$ & $123.5 \mathrm{~B}$ & $1.67 \mathrm{ab}$ & 1.37 ef & $1.22 \mathrm{gh}$ & $1.42 \mathrm{AB}$ \\
\hline Mean & $131.1 \mathrm{~A}$ & $115.4 \mathrm{~B}$ & $107.1 \mathrm{C}$ & & $1.60 \mathrm{~A}$ & $1.32 \mathrm{~B}$ & $1.17 \mathrm{C}$ & \\
\hline
\end{tabular}

- Means having the same letter (s) in a column or line are not significantly different at $5 \%$ level

- Starting date May $15^{\text {th }}$ for plant height $(\mathrm{cm})$ recorded 83.3 and $88.5 \mathrm{~cm}$ for 2018 and 2019 season

- Starting date May $15^{\text {th }}$ for stem diameter $(\mathrm{cm})$ recorded 0.84 and $0.89 \mathrm{~cm}$ for 2018 and 2019 season 
3.2 Average number/ seedlings of leaves and average leaf area $\left(\mathrm{cm}^{2}\right)$

\subsubsection{Average number of leaves}

It is clear from data in Table 2 that, the low concentrations of anti-stress materials gave more leaves than higher concentrations or control. However, spraying apple seedlings with $1.0 \mathrm{mM}$ MeJA and $0.5 \%$ chitosan as well as untreated seedlings gave the highest values (203.3, 200.6 and 205.1 in $1^{\text {st }}$ season \& $183.6,188.9$ and 191.6 in $2^{\text {nd }}$ season) of the leaves number. However, the $2.0 \mathrm{mM}$ MeJA slightly differences than $1 \%$ chitosan and the control where they recorded the lowest significant values of leaves number (190.6, 193.3 and 195.5 in the first season) \& (176.5, 177.6 and 180.3 in the second season) respectively.

Regarding water regiem effect, it clear that irrigated plants with $100 \%$ of the recommended water (no water stress) exhibited the lowest values of leaves number/ plant. Whereas, the highest level of water stress $(60 \%)$ produced more leaves number / plant for both seasons.

The highest interaction values (215.5 and 201.5 leaves/plant) were obtained with unsprayed plants and irrigated with $60 \%$ recommended water in first and second seasons. Under study. However ,the lowest interaction values register with seedlings irrigated with $100 \%$ of recommended water regiem and sprayed $2.0 \mathrm{mM}$ MeJA or $1 \%$ chitosan (188.00 \& 189.25 and 172.25 \&175.00 leaves / plant) for both seasons. It is worth noting that, the leaves of these treatments were more freshness and larger in size.

\subsubsection{Leaf area}

It is clear from data in Table 2 that leaf area greatly affected with water stress levels and spraying of anti-stress materials, it is noted that leaf area took opposite trend to those found in the leaves number. Water applied at $100 \%$ level exhibited the largest leaves in the both seasons $(28.9 \mathrm{~cm} 2 \mathrm{in}$ 2018 and $30.3 \mathrm{~cm} 2$ in 2019). However, $60 \%$ of water regiem negatively affected leaves area values which recorded the smallest one $\left(19.0 \& 20.9 \mathrm{~cm}^{2}\right)$ in 2018 and 2019 seasons respectively. The highest significant values of leaf area were recorded with $2.0 \mathrm{mM}$ MeJA (26.3 and $27.9 \mathrm{~cm}^{2}$ ), $1 \%$ chitosan ( 25.5 and $26.6 \mathrm{~cm}^{2}$ ) and the control (25.4 and 27.2 $\mathrm{cm}^{2}$ ) in the $1^{\text {st }}$ and $2^{\text {nd }}$ seasons respectively. Moreover, the untreated seedlings recorded the minimal values in this respect. Interaction values were higher and significant with apple seedlings irrigated with $100 \%$ recommended water and treated with $1.0 \%$ Chitosan or $2.0 \mathrm{mM}$ MeJA in both studied seasons. On the contrary, untreated apple seedling irrigated with $60 \%$ recommended water recorded the smallest leaf area.

The good sized impact of chitosan on plant growth may be attributed to an increase in the enzyme activities of nitrogen metabolism (nitrate reductive, glutamine synthetize and protease) and elevated photosynthesis which improve the plant growth (Mondal et al 2012). However, El-Bassiony et al (2014) pronounced that, chitosan result in to synthesize plant hormones example gibberellins, additionally, it enhances growth through a few signaling pathways associated with auxin biosynthesis via a tryptophan in structured pathway. Moreover, chitosan may be due to an increase in the availability and uptake of water and important nutrients by adjusting cellular osmotic pressure through increasing antioxidants and enzyme action (Guan et al 2009).

\subsection{Number of branches and shoot length}

\subsubsection{Number of branches}

Number of branches values of Table 3 was affected with all used irrigation treatments, where the seedlings irrigated with $100 \%$ of recommended water achieved the less shoot number (8.67 \&8.13) in the both seasons. However irrigation with the least amount of recommended water $(60 \%)$ produced the highest number of branches (13.05 and 12.13). Regarding the effect of the used treatments, it is clear that, methyl jasmonate at $2.0 \mathrm{mM}$ was recorded the lower number of branches / plant (9.17 \& 8.67) than other treatments or untreated. Whereas untreated apple seedlings manifest contrary direction which were recorded the highest number of branches (12.67 \& 11.67) in both seasons.

The interaction values showed that $100 \%$ of recommended water regiem with $2 \mathrm{mM}$ of methyl jasmonate recorded the lowest number of branches. Moreover, irrigation by $80 \%$ of water regiem with all applied treatments were similar to control seedlings in the number of branchs with slightly differences between them. On the other hand, all untreated seedlings recorded the highest number of branches at $60 \%$ of recommended. water It is well known that, the increase of lateral branches are considered an indicator to stress symptoms, so any treatment decrease lateral branches values are important due to its important role in avoiding stress effect. 

apple seedlings grown under water and heat stress conditions

Table 2. Effect of methyl jasmonate and chitosan application on total number of leaves and leaf area $\left(\mathrm{cm}^{2}\right)$ of "Anna" apple seedlings grown under water and heat stresses conditions during 2018 and 2019 seasons

\begin{tabular}{|c|c|c|c|c|c|c|c|c|}
\hline \multirow{3}{*}{ Treatments } & \multicolumn{4}{|c|}{ No. leaves/ seedling } & \multicolumn{4}{|c|}{ Leaf area $(\mathrm{cm} 2)$} \\
\hline & \multicolumn{3}{|c|}{ Recommended water regiem } & \multirow{2}{*}{ Mean } & \multicolumn{3}{|c|}{ Recommended water regiem } & \multirow{2}{*}{ Mean } \\
\hline & $100 \%$ & $80 \%$ & $60 \%$ & & $100 \%$ & $80 \%$ & $60 \%$ & \\
\hline \multicolumn{9}{|c|}{ First Season } \\
\hline MeJA $1.0 \mathrm{mM}$ & $198.25 \mathrm{~cd}$ & $204.00 b c$ & $207.75 a b$ & $203.3 \mathrm{~A}$ & $28.1 \mathrm{bc}$ & $24.2 \mathrm{e}$ & $18.1 \mathrm{gh}$ & $23.5 \mathrm{C}$ \\
\hline MeJA $2.0 \mathrm{mM}$ & $188.00 \mathrm{f}$ & $187.50 \mathrm{f}$ & 196.25 c-e & $190.6 \mathrm{C}$ & $29.7 \mathrm{ab}$ & $26.4 \mathrm{~cd}$ & 23.0 ef & $26.3 \mathrm{~A}$ \\
\hline Chitosan $0.5 \%$ & $198.75 \mathrm{~cd}$ & $200.75 b-d$ & $202.25 \mathrm{bc}$ & $200.6 \mathrm{AB}$ & $28.4 \mathrm{bc}$ & $23.5 \mathrm{e}$ & $16.4 \mathrm{~h}$ & $22.8 \mathrm{C}$ \\
\hline Chitosan $1.0 \%$ & 189.25 ef & $194.0 \mathrm{~d}-\mathrm{f}$ & $196.50 \mathrm{c}-\mathrm{e}$ & $193.3 \mathrm{C}$ & $30.9 \mathrm{a}$ & $25.3 \mathrm{de}$ & $20.0 \mathrm{fg}$ & $25.5 \mathrm{~A}$ \\
\hline Untreated & $193.50 \mathrm{~d}-\mathrm{f}$ & $206.25 \mathrm{~b}$ & $215.50 \mathrm{a}$ & $205.1 \mathrm{~A}$ & $26.7 \mathrm{~cd}$ & $21.2 \mathrm{f}$ & $14.6 \mathrm{i}$ & $.208 \mathrm{D}$ \\
\hline Control & $194.75 d-f$ & $192.50 d-f$ & $199.25 \mathrm{~b}-\mathrm{d}$ & $195.5 \mathrm{BC}$ & $29.3 \mathrm{ab}$ & $25.3 \mathrm{de}$ & $21.6 \mathrm{f}$ & $25.4 \mathrm{~A}$ \\
\hline Mean & $193.8 \mathrm{~B}$ & $197.5 \mathrm{~B}$ & $203.0 \mathrm{~A}$ & & $28.9 \mathrm{~A}$ & $24.4 \mathrm{~B}$ & $19.0 \mathrm{C}$ & \\
\hline \multicolumn{9}{|c|}{ Second Season } \\
\hline MeJA $1.0 \mathrm{mM}$ & 180.25 c-e & $183.50 \mathrm{c}-\mathrm{e}$ & $187.25 \mathrm{~cd}$ & $183.6 \mathrm{~B}$ & $30.5 \mathrm{ab}$ & $26.3 \mathrm{de}$ & $20.9 \mathrm{~h}$ & $25.9 \mathrm{C}$ \\
\hline MeJA $2.0 \mathrm{mM}$ & $172.25 \mathrm{f}$ & 177.5 ef & $179.75 d-f$ & $176.5 \mathrm{C}$ & $32.2 \mathrm{a}$ & $28.4 \mathrm{bc}$ & $23.1 \mathrm{fg}$ & $27.9 \mathrm{~A}$ \\
\hline Chitosan $0.5 \%$ & $182.50 \mathrm{c}-\mathrm{e}$ & $188.25 \mathrm{bc}$ & $196.0 \mathrm{ab}$ & $188.9 \mathrm{~A}$ & $28.8 \mathrm{bc}$ & 24.5 ef & $19.8 \mathrm{~h}$ & $24.4 \mathrm{D}$ \\
\hline Chitosan $1.0 \%$ & 175.00 ef & 176.75 ef & $181.4 \mathrm{c}-\mathrm{e}$ & $177.6 \mathrm{C}$ & $31.1 \mathrm{a}$ & $27.2 \mathrm{~cd}$ & $21.6 \mathrm{gh}$ & $26.6 \mathrm{BC}$ \\
\hline Untreated & $186.00 \mathrm{~cd}$ & $187.25 \mathrm{~cd}$ & $201.50 \mathrm{a}$ & $191.6 \mathrm{~A}$ & $27.3 \mathrm{~cd}$ & $22.7 \mathrm{fg}$ & $17.3 \mathrm{i}$ & $22.4 \mathrm{E}$ \\
\hline Control & 176.50 ef & $181.00 \mathrm{c}-\mathrm{e}$ & 183.25 c-e & 180.3 BC & $31.6 \mathrm{a}$ & $27.6 \mathrm{~cd}$ & $22.5 \mathrm{fg}$ & $27.2 \mathrm{AB}$ \\
\hline Mean & $178.8 \mathrm{~B}$ & $181.0 \mathrm{~B}$ & $188.2 \mathrm{~A}$ & & $30.3 \mathrm{~A}$ & $26.1 \mathrm{~B}$ & $20.9 \mathrm{C}$ & \\
\hline
\end{tabular}

Table 3. Effect of methyl jasmonate and Chitosan application on number of branches/seedling and shoot length (cm) of Anna apple seedlings grown under water and heat stresses conditions during 2018 and 2019 seasons.

\begin{tabular}{|c|c|c|c|c|c|c|c|c|}
\hline \multirow{3}{*}{ Treatments } & \multicolumn{4}{|c|}{ Number of branches/seedling } & \multicolumn{4}{|c|}{ Shoot length (cm) } \\
\hline & \multicolumn{3}{|c|}{ Recommended water regiem } & \multirow{2}{*}{ Mean } & \multicolumn{3}{|c|}{ Recommended water regiem } & \multirow{2}{*}{ Mean } \\
\hline & $100 \%$ & $80 \%$ & $60 \%$ & & $100 \%$ & $80 \%$ & $60 \%$ & \\
\hline \multicolumn{9}{|c|}{ First Season } \\
\hline MeJA $1.0 \mathrm{mM}$ & $8.75 \mathrm{fg}$ & $11.00 \mathrm{c}-\mathrm{e}$ & $13.00 \mathrm{bc}$ & $10.92 \mathrm{BC}$ & $40.2 \mathrm{bc}$ & $31.6 \mathrm{fg}$ & $25.7 \mathrm{i}$ & $32.5 \mathrm{BC}$ \\
\hline MeJA $2.0 \mathrm{mM}$ & $7.25 \mathrm{~g}$ & $9.00 \mathrm{e}-\mathrm{g}$ & $11.25 \mathrm{~cd}$ & $9.17 \mathrm{D}$ & $43.4 \mathrm{a}$ & 34.3 ef & $27.4 \mathrm{hi}$ & $35.2 \mathrm{~A}$ \\
\hline Chitosan $0.5 \%$ & 9.25 ef & $11.50 \mathrm{~cd}$ & $14.00 \mathrm{ab}$ & $11.58 \mathrm{AB}$ & $37.9 \mathrm{~cd}$ & $29.7 \mathrm{gh}$ & $24.4 \mathrm{i}$ & $30.7 \mathrm{C}$ \\
\hline Chitosan $1.0 \%$ & $8.50 \mathrm{fg}$ & $10.25 d-f$ & $12.75 \mathrm{bc}$ & $10.50 \mathrm{C}$ & $38.9 \mathrm{~b}-\mathrm{d}$ & $31.2 \mathrm{fg}$ & 26.6 hi & $32.2 \mathrm{BC}$ \\
\hline Untreated & $10.00 \mathrm{~d}-\mathrm{f}$ & $12.75 \mathrm{bc}$ & $15.25 \mathrm{a}$ & $12.67 \mathrm{~A}$ & $36.3 \mathrm{de}$ & $27.2 \mathrm{hi}$ & $21.9 j$ & $28.5 \mathrm{D}$ \\
\hline Control & $8.25 \mathrm{fg}$ & $9.75 \mathrm{~d}-\mathrm{f}$ & $12.00 \mathrm{bc}$ & $10.00 \mathrm{CD}$ & $41.1 \mathrm{ab}$ & 33.6 ef & $26.9 \mathrm{hi}$ & $33.9 \mathrm{AB}$ \\
\hline Mean & $8.67 \mathrm{C}$ & $10.71 \mathrm{~B}$ & $13.05 \mathrm{~A}$ & & $39.7 \mathrm{~A}$ & $31.3 \mathrm{~B}$ & $25.4 \mathrm{C}$ & \\
\hline \multicolumn{9}{|c|}{ Second Season } \\
\hline MeJA $1.0 \mathrm{mM}$ & $8.00 \mathrm{hi}$ & $10.50 \mathrm{de}$ & $12.25 \mathrm{bc}$ & $10.25 \mathrm{BC}$ & $38.8 \mathrm{ab}$ & $33.7 \mathrm{c}-\mathrm{e}$ & $27.0 \mathrm{~g}$ & $33.2 \mathrm{AB}$ \\
\hline MeJA $2.0 \mathrm{mM}$ & $7.25 \mathrm{i}$ & $8.50 \mathrm{~g}-\mathrm{i}$ & $10.50 \mathrm{de}$ & $8.67 \mathrm{D}$ & $40.1 \mathrm{a}$ & $35.2 \mathrm{~cd}$ & $28.2 \mathrm{fg}$ & $34.5 \mathrm{~A}$ \\
\hline Chitosan $0.5 \%$ & $9.00 \mathrm{f}-\mathrm{g}$ & $10.25 d-f$ & $13.25 \mathrm{ab}$ & $10.83 \mathrm{AB}$ & $36.5 \mathrm{bc}$ & 31.1 ef & $23.9 \mathrm{ab}$ & $30.5 \mathrm{C}$ \\
\hline Chitosan $1.0 \%$ & $7.25 \mathrm{i}$ & $9.75 \mathrm{e}-\mathrm{g}$ & $11.75 b-d$ & $9.58 \mathrm{CD}$ & $36.4 \mathrm{bc}$ & $32.6 \mathrm{de}$ & $28.6 \mathrm{fg}$ & $32.5 \mathrm{~B}$ \\
\hline Untreated & $9.75 \mathrm{e}-\mathrm{g}$ & $11.25 \mathrm{~cd}$ & $14.00 \mathrm{a}$ & $11.67 \mathrm{~A}$ & 31.8 ef & $25.8 \mathrm{gh}$ & $19.1 \mathrm{i}$ & $25.6 \mathrm{C}$ \\
\hline Control & $7.75 \mathrm{hi}$ & $9.00 \mathrm{f}-\mathrm{g}$ & $11.00 \mathrm{c}-\mathrm{e}$ & $9.28 \mathrm{CD}$ & $39.3 a b$ & $34.9 \mathrm{~cd}$ & $27.5 \mathrm{~g}$ & $33.9 \mathrm{AB}$ \\
\hline Mean & $8.13 \mathrm{C}$ & $9.88 \mathrm{~B}$ & $12.13 \mathrm{C}$ & & $37.2 \mathrm{~A}$ & $32.2 \mathrm{~B}$ & $25.7 \mathrm{C}$ & \\
\hline
\end{tabular}




\subsubsection{Shoot length}

Table 3 data showed that apple seedlings irrigated with $100 \%$ of recommended water exhibited higher values of shoot length (39.7 in the first season and $37.2 \mathrm{~cm}$ in the second season) than those irrigated under water stress (80 or $60 \%$ ). For instance, the plants irrigated with $60 \%$ recommended water produced the shortest shoots (25.4 and 25.7 $\mathrm{cm}$ ) in both seasons.

Methyl jasmonate at $2.0 \mathrm{mM}$ and Chitosan at $1.0 \%$ were superior than other treatments or untreated in recording the longest shoots $(35.2$ \& 32.2 $\mathrm{cm}$ in $1^{\text {st }}$ season and $34.5 \& 32.5$ in $2^{\text {nd }}$ season, whereas untreated apple seedlings recorded the shortest shoots (28.5 and 25.6) in both seasons Interaction between the two studied factors was significant in affecting shoot length of apple seedling, where the highest interaction values were recorded by apple seedlings irrigated with $100 \%$ of recommended water and sprayed $2.0 \mathrm{mM}$ Methyl jasmonate. However, the seedlings irrigated with $60 \%$ recommended water and treated with $0.5 \%$ chitosan or untreated, showed the little effect and produced the shortest shoots.

The great effect to chitosan could be attributed to its stimulate effect on physiological pathways vigrour growth vegetative and finally followed by translocation of net assimilation from source (roots) to sink (fruits) organs. The improvement in plant vigour could be explained by improving mechanism of photosynthetic process (Khan et al 2002). Inaddition, the favourable effect to chitosan in escaping from the disorder effect to water difict or less water quality on yield and quality is attributed to the increase of conductivity of stomata and final product of photosynthetic $\mathrm{CO}_{2}$-fixation pathway under water stress (Khan et al 2002). However. Mondal et al (2013) explained the great role to chitosan through reduction in transpiration to bound water. The obtained data are in harmony with Wang (2012) who indicated to the great to methyl jasmonate in reduing water losses throught leaves pores in water stressed irrigated. Additionally, Rohwer and Erwin (2008), explained the reduction of water losses throught apical shoots suffering from water stress in response to methyl jasmonate treatments due to the regulation role to methyl jasmonate on clouser of stomata system followed by promoting ability of different plant organs for water use.

\subsubsection{Fresh and dry weights of seedlings}

Table 4 showed that the fresh and dry weights of apple seedling greatly affected with the both studied factors during the two studied seasons. Irrigated apple seedlings with $100 \%$ of recommended water was recorded higher values of fresh and dry weight $(255.4,109.5 \mathrm{~g} / \mathrm{seedling}$ for 2018 season and $277.7,115.9 \mathrm{~g} /$ seedling for 2019 season) than those irrigated with $60 \%$ of recommended water (188.8, $74.9 \mathrm{~g} /$ seedling in 2018 season and 203.2, $78.2 \mathrm{~g} /$ seedling in 2019 season).

Application of anti-stress treatments greatly improved both fresh and dry weights of apple seedlings where they were similar to the control or better. Methyl jasmonate at $2.0 \mathrm{mM}$ was superior than others where it achieved the highest significant values of fresh and dry weight $\left(236.0 \& 99.2 \mathrm{~g}\right.$ in the $1^{\text {st }}$ season and $251.9 \& 103.4 \mathrm{~g}$ in $2^{\text {nd }}$ season) respectively. Slightly differences were recorded between the control and chitosan at $1.0 \%$ in their impact on both fresh and dry weights which comes after the previous treatment. Whereas the untreated plants recorded lowest values $(187.4,77.1 \mathrm{~g}$ and 199.9, $80.9 \mathrm{~g}$ in both seasons respectively).

Interaction values were significant in most cases, where the high-concentration of both methyl jasmonate and chitosan treatments under all levels of water recommended led to protecting plants from water and heat stress. However, the fresh and dry weights values of these treatments were identical with the plants growing in normal conditions without water stress or heat stress (control treatment). The highest interaction values of fresh and dry weights were combined with the seedlings irrigated $100 \%$ of water regiem and sprayed by with $2 \mathrm{mM}$ MeJA (286.2, $122.5 \mathrm{~g}$ and 297.8,127.5 g), 1.0\% chitosan $(270.3,123.6 \mathrm{~g}$ and $287.6,123.6 \mathrm{~g})$ and control $(263.4,119.7 \mathrm{~g}$ and $289.3,120.3 \mathrm{~g})$ in the $1^{\text {st }}$ and $2^{\text {nd }}$ seasons respectively. On the contrary, the untreated seedlings with $60 \%$ of water stress recorded the lowest significant value (161.9 \& 65.8 in 2018 and $173.8 \& 67.9 \mathrm{~g}$ in 2019).

The improving role to chitosan on plant development could be explained by the promoting effect to chitosan on physiological pathways and hastening the transportation of nitrogen in the active leaves which perfected plant vigourus (Gornik et al 2008). In addition Balusamy et al (2015) montioned that spraying of exogenous MeJA was effective in leves wounding recorery of Panax ginseng leaves from wounding. However, Moreira et al (2012) reported that methyl jasmonate will be used as a chemical elicitor in younger conifer trees to increase its ability to resist stress conditions through rising seedlings survival percentage. 

apple seedlings grown under water and heat stress conditions

Table 4. Effect of methyl jasmonate and chitosan application on plant fresh weight (g) and plant dry weight (g) of "Anna" apple seedlings grown under water and heat stresses conditions during 2018 and 2019 seasons.

\begin{tabular}{|c|c|c|c|c|c|c|c|c|}
\hline \multirow{3}{*}{ Treatments } & \multicolumn{4}{|c|}{ Plant fresh weight $(\mathrm{g})$} & \multicolumn{4}{|c|}{ Plant dry weight (g) } \\
\hline & \multicolumn{3}{|c|}{ Recommended water regiem } & \multirow{2}{*}{ Mean } & \multicolumn{3}{|c|}{ Recommended water regiem } & \multirow{2}{*}{ Mean } \\
\hline & $100 \%$ & $80 \%$ & $60 \%$ & & $100 \%$ & $80 \%$ & $60 \%$ & \\
\hline \multicolumn{9}{|c|}{ First Season } \\
\hline MeJA $1.0 \mathrm{mM}$ & $254.9 \mathrm{bc}$ & $217.4 \mathrm{e}$ & $191.4 \mathrm{fg}$ & $221.2 \mathrm{C}$ & $106.2 \mathrm{~b}$ & $89.1 \mathrm{de}$ & $74.2 \mathrm{~g}$ & $89.8 \mathrm{C}$ \\
\hline MeJA $2.0 \mathrm{mM}$ & $286.2 \mathrm{a}$ & $220.1 \mathrm{de}$ & 201.6 ef & $236.0 \mathrm{~A}$ & $122.5 \mathrm{a}$ & $95.7 \mathrm{~cd}$ & $79.3 \mathrm{fg}$ & $99.2 \mathrm{~A}$ \\
\hline Chitosan $0.5 \%$ & $239.4 \mathrm{~cd}$ & 203.1 ef & $181.5 \mathrm{~g}$ & $208.2 \mathrm{D}$ & $101.9 \mathrm{bc}$ & 83.6 ef & $72.2 \mathrm{gh}$ & $85.9 \mathrm{D}$ \\
\hline Chitosan $1.0 \%$ & $270.3 a b$ & $217.5 \mathrm{e}$ & $195.6 \mathrm{fg}$ & $227.8 \mathrm{BC}$ & $114.8 \mathrm{a}$ & $93.6 \mathrm{~cd}$ & $78.6 \mathrm{fg}$ & $95.1 \mathrm{~B}$ \\
\hline Untreated & $218.4 \mathrm{~d}$ & $181.8 \mathrm{~g}$ & $161.9 \mathrm{~h}$ & $187.4 \mathrm{E}$ & $91.8 \mathrm{~d}$ & $73.7 \mathrm{gh}$ & $65.8 \mathrm{~h}$ & $77.1 \mathrm{E}$ \\
\hline Control & $263.4 \mathrm{~b}$ & $237.4 \mathrm{~cd}$ & 200.8 ef & $233.9 \mathrm{AB}$ & $119.7 \mathrm{a}$ & $92.0 \mathrm{~d}$ & $79.4 \mathrm{fg}$ & $97.0 \mathrm{AB}$ \\
\hline Mean & $255.4 \mathrm{~A}$ & $212.9 \mathrm{~B}$ & $188.8 \mathrm{C}$ & & $109.5 \mathrm{~A}$ & $87.9 \mathrm{~B}$ & $74.9 \mathrm{C}$ & \\
\hline \multicolumn{9}{|c|}{ Second Season } \\
\hline MeJA $1.0 \mathrm{mM}$ & $274.3 \mathrm{~b}$ & $231.3 \mathrm{~cd}$ & 201.1 ef & $235.6 \mathrm{C}$ & $112.4 b$ & $94.0 \mathrm{~cd}$ & $78.7 \mathrm{fg}$ & $95.0 \mathrm{C}$ \\
\hline MeJA $2.0 \mathrm{mM}$ & $297.8 \mathrm{a}$ & $246.4 \mathrm{C}$ & $211.6 \mathrm{e}$ & $251.9 \mathrm{~A}$ & $127.5 \mathrm{a}$ & $101.1 \mathrm{c}$ & $81.6 \mathrm{fg}$ & $103.4 \mathrm{~A}$ \\
\hline Chitosan $0.5 \%$ & $282.0 \mathrm{ab}$ & $231.8 \mathrm{~cd}$ & 205.0 ef & $239.6 \mathrm{BC}$ & $115.1 \mathrm{~b}$ & $92.3 \mathrm{de}$ & $76.1 \mathrm{~g}$ & $94.5 \mathrm{C}$ \\
\hline Chitosan $1.0 \%$ & $287.6 a b$ & $236.5 \mathrm{~cd}$ & 210.7 e & $244.9 \mathrm{AB}$ & $123.6 \mathrm{a}$ & $96.6 \mathrm{~cd}$ & $79.2 \mathrm{fg}$ & $99.8 \mathrm{~B}$ \\
\hline Untreated & $235.4 \mathrm{~cd}$ & $190.4 \mathrm{fg}$ & $173.8 \mathrm{~g}$ & $199.9 \mathrm{D}$ & $96.2 \mathrm{~cd}$ & $78.5 \mathrm{fg}$ & $67.9 \mathrm{~h}$ & $80.9 \mathrm{D}$ \\
\hline Control & $289.3 \mathrm{ab}$ & $241.3 \mathrm{c}$ & $217.1 \mathrm{de}$ & $249.2 \mathrm{~A}$ & $120.3 a b$ & $94.6 \mathrm{~cd}$ & 85.4 ef & $100.1 \mathrm{AB}$ \\
\hline Mean & $277.7 \mathrm{~A}$ & $229.6 \mathrm{~B}$ & $203.2 \mathrm{C}$ & & $115.9 \mathrm{~A}$ & $92.9 \mathrm{~B}$ & $78.2 \mathrm{C}$ & \\
\hline
\end{tabular}

- Means having the same letter (s) in a column or line are not significantly different at $5 \%$ level

- Starting date May $15^{\text {th }}$ Fresh weight $(\mathrm{g})$ recorded 156.2 and $172.3(\mathrm{~g})$ for 2018 and 2019 seasons

- Starting date May $15^{\text {th }}$ dry weight $(\mathrm{g})$ recorded 67.18 and 72.37 (g) for 2018 and 2019 seasons

\subsection{Leaf mineral contents}

\subsubsection{N, P, K, Ca and $\mathrm{Mg} \%$}

\subsubsection{N, P and K (\%)}

Data in Table 5 show the effect of two types of stresses (heat or water), anti-stress treatments and their interactions on $\mathrm{N}, \mathrm{P}$ and $\mathrm{K} \%$ of apple seedlings. The highest values of $\mathrm{N}, \mathrm{P}$ and $\mathrm{K} \%$ were appeared with apple seedlings irrigated with $100 \%$ of recommended water $(2.64,2.71 \%$ for $\mathrm{N}, 0.25,0.30$ $\%$ for $\mathrm{P}$ and $1.95,2.23 \%$ for $\mathrm{K}$ in 2018 and 2019 seasons respectively.

Leaf mineral contents were decreased with persistent water stress $(60 \%)$ where recorded the lowest values of the mineral element. However, all antistress treatments were effective in increasing of $\mathrm{N}$, $\mathrm{P}$ and $\mathrm{K}$ levels compared to untreated seedlings, methyl jasmonate at $2.0 \mathrm{mM}$ and chitosan at $1.0 \%$ treatments were more effective in this respect than other. Low concentrations of anti- stress material affected on the level mineral elements with medium values slightly less than the control and high than the untreated seedlings. Interaction between the two studied factors was significant in most cases, where the highest values of $\mathrm{N}, \mathrm{P}$ and $\mathrm{K}$ were recorded by apple seedlings irrigated with $100 \%$ water regiems and sprayed with the $1.0 \%$ chitosan in first season of study. However, the least interaction values of $\mathrm{N}, \mathrm{P}$ and $\mathrm{K}$ were recorded by untreated "Anna" apple seedlings and irrigated with $60 \%$ of the water quantity.

\subsubsection{2 $\mathrm{Ca}$ and $\mathrm{Mg} \%$}

As it is illustrated in Table 6, it is clear that the two studied factors greatly increased nutritions status represented in $\mathrm{Ca}$ and $\mathrm{Mg}$ levels in apple seedlings. Irrigation with $100 \%$ of recommended water exhibited the highest $\mathrm{Ca} \%$ and $\mathrm{Mg} \%$ in both studied seasons, compared to those plants irrigated with $80 \%$ or $60 \%$ of recommended water. All applied treatments recorded high values of $\mathrm{Ca} \%$ and $\mathrm{Mg} \%$ than untreated ones, chitosan at $1.0 \%$ and jasmonate at $2.0 \mathrm{mM}$ as well as the control treatments were effective in improving $\mathrm{Ca} \%$ and $\mathrm{Mg} \%$ of apple seedlings, $1.0 \%$ chitosan achieved highest values of 1.74 and $1.79 \mathrm{Ca} \%, 0.40 \& 0.45 \mathrm{Mg} \%$ for 2018 and 2019 seasons. Interaction values were higher with the two added anti-stress treatments (2.0 mMJA and $1 \%$ chitosan) in combination with $100 \%$ of water regiem followed by the same treatments with $80 \%$ of water regiem. 


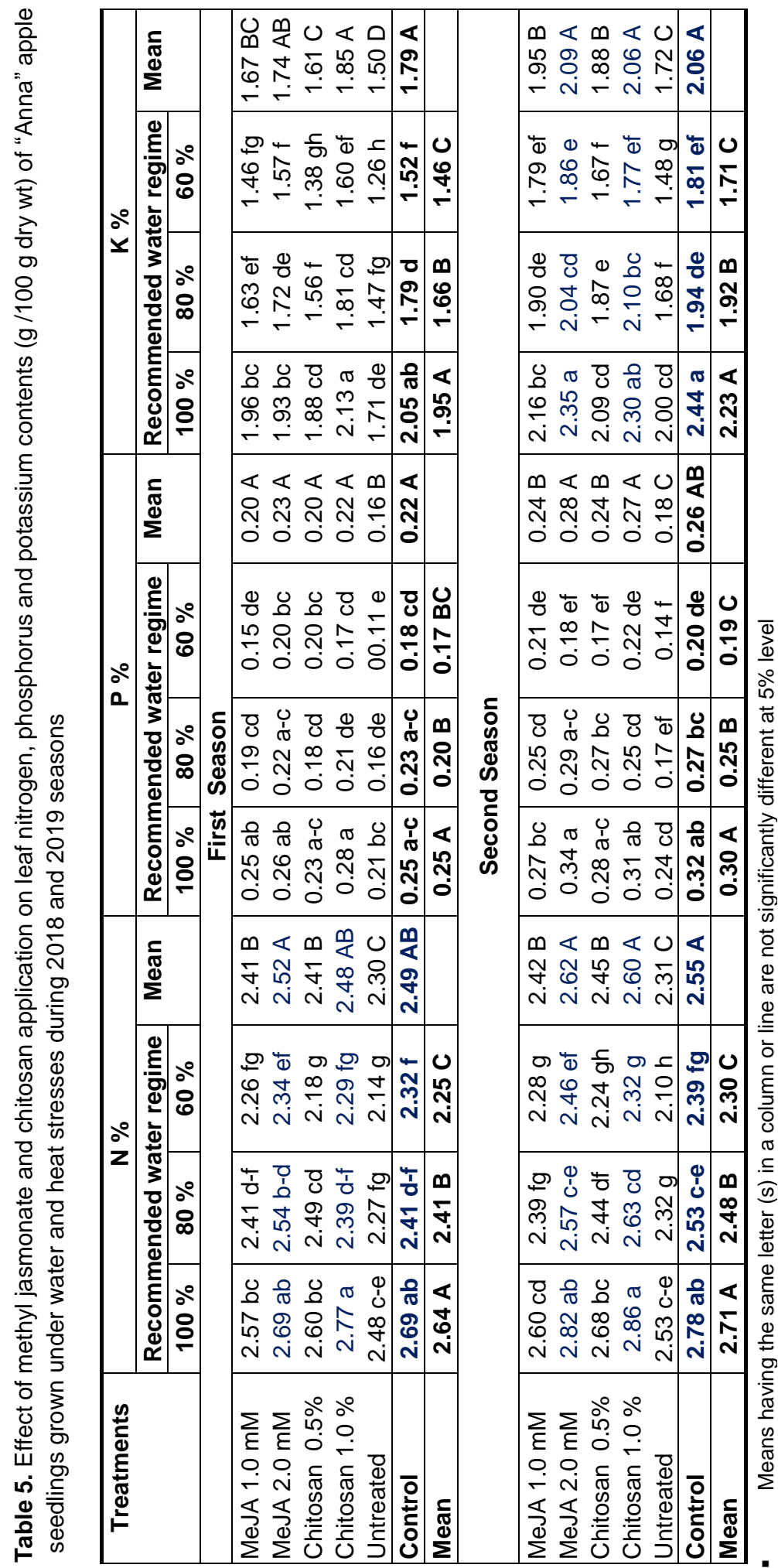


Table 6. Effect of methyl jasmonate and chitosan application on leaf calcium and magnesium content ( $\mathrm{g} / 100 \mathrm{~g}$ dry $\mathrm{wt}$ ) of "Anna" apple seedlings grown under water and heat stresses conditions during 2018 and 2019 seasons

\begin{tabular}{|c|c|c|c|c|c|c|c|c|}
\hline \multirow{3}{*}{ Treatments } & \multicolumn{4}{|c|}{ Calcium \% } & \multicolumn{4}{|c|}{\begin{tabular}{r|} 
Magnesium \% \\
\end{tabular}} \\
\hline & \multicolumn{3}{|c|}{ Recommended water regiem } & \multirow{2}{*}{ Mean } & \multicolumn{3}{|c|}{ Recommended water regiem } & \multirow{2}{*}{ Mean } \\
\hline & $100 \%$ & $80 \%$ & $60 \%$ & & $100 \%$ & $80 \%$ & $60 \%$ & \\
\hline \multicolumn{9}{|c|}{ First Season } \\
\hline MeJA $1.0 \mathrm{mM}$ & $1.75 \mathrm{~cd}$ & $1.60 \mathrm{de}$ & $1.37 f$ & $1.59 \mathrm{C}$ & $0.43 \mathrm{~cd}$ & 0.34 ef & $0.30 \mathrm{fg}$ & $0.36 \mathrm{~B}$ \\
\hline MeJA $2.0 \mathrm{mM}$ & $1.92 a b$ & $1.62 \mathrm{de}$ & 1.46 ef & $1.67 \mathrm{AB}$ & $0.52 \mathrm{a}$ & $0.46 \mathrm{bc}$ & $0.31 \mathrm{fg}$ & $0.43 \mathrm{~A}$ \\
\hline Chitosan $0.5 \%$ & $1.83 \mathrm{bc}$ & 1.55 ef & $1.42 \mathrm{f}$ & $1.60 \mathrm{BC}$ & $0.44 \mathrm{bc}$ & $0.37 \mathrm{de}$ & $0.27 \mathrm{~g}$ & $0.36 \mathrm{~B}$ \\
\hline Chitosan $1.0 \%$ & $2.08 \mathrm{a}$ & $1.75 \mathrm{~cd}$ & $1.40 \mathrm{f}$ & $1.74 \mathrm{~A}$ & $0.46 \mathrm{bc}$ & $0.41 \mathrm{~cd}$ & 0.33 ef & $0.40 \mathrm{~A}$ \\
\hline Untreated & $1.61 \mathrm{de}$ & 1.47 ef & $1.18 \mathrm{~g}$ & $1.42 \mathrm{D}$ & $0.36 \mathrm{de}$ & $0.28 \mathrm{~g}$ & $0.21 \mathrm{~h}$ & $0.28 \mathrm{C}$ \\
\hline Control & $1.98 \mathrm{ab}$ & $1.66 \mathrm{~cd}$ & 1.47 ef & $1.70 \mathrm{AB}$ & $0.49 a b$ & $0.42 \mathrm{~cd}$ & 0.35 ef & $0.42 \mathrm{~A}$ \\
\hline Mean & $1.86 \mathrm{~A}$ & $1.61 \mathrm{~B}$ & $1.38 \mathrm{C}$ & & $0.45 \mathrm{~A}$ & $0.38 \mathrm{~B}$ & $0.30 \mathrm{C}$ & \\
\hline \multicolumn{9}{|c|}{ Second Season } \\
\hline MeJA $1.0 \mathrm{mM}$ & $1.97 \mathrm{bc}$ & 1.56 ef & $1.32 \mathrm{gh}$ & $1.62 \mathrm{~B}$ & $0.48 \mathrm{c}$ & $0.40 \mathrm{de}$ & $0.31 \mathrm{f}$ & $0.42 \mathrm{C}$ \\
\hline MeJA $2.0 \mathrm{mM}$ & $2.13 a b$ & $1.82 \mathrm{~cd}$ & $1.50 \mathrm{fg}$ & $1.82 \mathrm{~A}$ & $0.58 a b$ & $0.48 c$ & $0.39 \mathrm{de}$ & $0.48 \mathrm{~A}$ \\
\hline Chitosan $0.5 \%$ & $2.05 a b$ & 1.63 ef & $1.27 \mathrm{hi}$ & $1.65 \mathrm{~B}$ & $0.53 \mathrm{~b}$ & $0.42 \mathrm{~cd}$ & $0.34 \mathrm{f}$ & $0.43 \mathrm{BC}$ \\
\hline Chitosan $1.0 \%$ & $2.21 \mathrm{a}$ & $1.84 \mathrm{~cd}$ & $1.33 \mathrm{gh}$ & $1.79 \mathrm{~A}$ & $0.55 b$ & $0.44 \mathrm{~cd}$ & 0.35 ef & $0.45 \mathrm{AB}$ \\
\hline Untreated & $1.74 \mathrm{de}$ & $1.39 \mathrm{gh}$ & $1.11 \mathrm{i}$ & $1.41 \mathrm{C}$ & $0.44 \mathrm{~cd}$ & $0.31 \mathrm{f}$ & $0.23 \mathrm{~g}$ & $0.33 \mathrm{D}$ \\
\hline Control & $2.24 \mathrm{a}$ & $1.78 \mathrm{c}-\mathrm{e}$ & $1.42 \mathrm{f}-\mathrm{h}$ & $1.81 \mathrm{~A}$ & $0.61 \mathrm{a}$ & $0.45 \mathrm{~cd}$ & 0.36 ef & $0.48 \mathrm{~A}$ \\
\hline Mean & $2.06 \mathrm{~A}$ & $1.67 \mathrm{~B}$ & $1.33 \mathrm{~B}$ & & $0.55 \mathrm{~A}$ & $0.43 \mathrm{~B}$ & $0.33 \mathrm{C}$ & \\
\hline
\end{tabular}

- Means having the same letter (s) in a column or line are not significantly different at $5 \%$ level

\subsubsection{Fe, $\mathrm{Zn}, \mathrm{Mn}$ and $\mathrm{Cu}(\mathrm{ppm})$}

In this regard in Tables $\mathbf{7}$ and $\mathbf{8}$ it is clear that $\mathrm{Fe}, \mathrm{Zn}, \mathrm{Mn}$ and $\mathrm{Cu}$ levels in apple seedlings greatly affected with both water stress and spraying of two anti-stresses martials. However, irrigated with $100 \%$ of the recommended water exhibited the highest $\mathrm{Mn}, \mathrm{Fe}, \mathrm{Zn}$ and $\mathrm{Cu}$ (ppm) in the two studied seasons with clear significant effects between them, meanwhile, plants irrigated with $60 \%$ of recommended water recorded the lowest values. Moreover, 2.0 $\mathrm{mM} \mathrm{JA}$ and $1.0 \%$ chitosan recorded the highest values of the four micro elements than other treatments or untreated in both studied seasons. However, no significant differences were obtained between the two mentioned treatments and the control seedling in this respect.

Interaction between the two studied factors was significant in most cases, the highest interaction values for $\mathrm{Fe}$ and $\mathrm{Zn}$ were achieved by seedlings irrigated with $100 \%$ water regiem and sprayed with higher concentration from chitosan or jasmonate materials. On the other hand the untreated seedlings under all irrigation water regiems recorded the least values in all the mentioned micro elements In this respect, Shehata et al (2012) mentioned that chitosan application significantly elevated $\mathrm{N}$ and $\mathrm{P}$ concentrations in addition to a few micro-nutrients (Fe, $\mathrm{Zn}, \mathrm{Cu}$ and $\mathrm{Mn}$ ) contents in fruits. El-Miniawy et al (2013) clarified that nitrogen content of leaves recorded increase with chitosan application compared with the control plant. Saif Eldeen et al (2014) showed that treated artichoke plants with chitosan significantly increased $\mathrm{N}$ and $\mathrm{P}$ contents, total sugars and\% protein, compared to the untreated plants. Farouk and Abd El Mohsen (2011) confirmed that use of chitosan at $250 \mathrm{mg} /$ liter led to a significant increase in nitrogen and Phosphoru contents. Jasmones act in the crop plant as a plant growth regulator and influence morphological, physiological and biochemical processes, associated with stress tolerance. It additionally activates plant protection mechanisms in reaction to various pathogens and environmental stresses. (Anjum et al 2011). 
Table 7. Effect of methyl jasmonate and chitosan application on leaf iron and manganese content (ppm) of "Anna" apple seedlings grown under water and heat stresses conditions during 2018 and 2019 seasons

\begin{tabular}{|c|c|c|c|c|c|c|c|c|}
\hline \multirow{3}{*}{ Treatments } & \multicolumn{4}{|c|}{ Fe (ppm) } & \multicolumn{4}{|c|}{ Mn (ppm) } \\
\hline & \multicolumn{3}{|c|}{ Recommended water regiem } & \multirow{2}{*}{ Mean } & \multicolumn{3}{|c|}{ Recommended water regiem } & \multirow{2}{*}{ Mean } \\
\hline & $100 \%$ & \begin{tabular}{|l|l}
$80 \%$ & \\
\end{tabular} & $60 \%$ & & $100 \%$ & $80 \%$ & $60 \%$ & \\
\hline \multicolumn{9}{|c|}{ First Season } \\
\hline MeJA $1.0 \mathrm{mM}$ & 165.7c-e & 151.4 ef & $119.7 \mathrm{~h}$ & $145.6 \mathrm{~B}$ & $76.3 \mathrm{~b}-\mathrm{d}$ & $60.7 \mathrm{fg}$ & $55.8 \mathrm{gh}$ & $64.3 \mathrm{~B}$ \\
\hline MeJA $2.0 \mathrm{mM}$ & $194.7 \mathrm{a}$ & $176.0 \mathrm{a}-\mathrm{c}$ & $142.4 \mathrm{fg}$ & $171.0 \mathrm{~A}$ & 88.4 a & $71.3 \mathrm{de}$ & $57.4 \mathrm{gh}$ & $72.3 \mathrm{~A}$ \\
\hline Chitosan $0.5 \%$ & $172.2 \mathrm{a}-\mathrm{c}$ & $156.7 \mathrm{~d}-\mathrm{f}$ & 128.1gh & $152.3 \mathrm{~B}$ & $73.0 \mathrm{c}-\mathrm{e}$ & $61.9 \mathrm{fg}$ & $51.2 \mathrm{~h}$ & $62.0 \mathrm{~B}$ \\
\hline Chitosan $1.0 \%$ & $183.3 \mathrm{ab}$ & $163.9 b-d$ & $138.6 \mathrm{fg}$ & $161.9 \mathrm{~A}$ & $80.4 \mathrm{a}-\mathrm{c}$ & 66.1 ef & $54.1 \mathrm{gh}$ & $66.9 \mathrm{AB}$ \\
\hline Untreated & 151.0 ef & $131.8 \mathrm{gh}$ & $101.2 \mathrm{i}$ & $128.0 \mathrm{C}$ & $68.5 \mathrm{de}$ & $56.4 \mathrm{gh}$ & $40.8 \mathrm{i}$ & $55.2 \mathrm{C}$ \\
\hline Control & $187.8 \mathrm{ab}$ & 169.3b-d & $146.5 \mathrm{fg}$ & $167.8 \mathrm{~A}$ & $83.1 \mathrm{ab}$ & $68.3 \mathrm{de}$ & $59.9 \mathrm{fg}$ & $70.4 \mathrm{~A}$ \\
\hline Mean & $175.7 \mathrm{~A}$ & $158.2 \mathrm{~B}$ & $129.0 \mathrm{C}$ & & $78.3 \mathrm{~A}$ & $64.1 \mathrm{~B}$ & $53.2 \mathrm{C}$ & \\
\hline \multicolumn{9}{|c|}{ Second Season } \\
\hline MeJA $1.0 \mathrm{mM}$ & $197.5 \mathrm{a}-\mathrm{c}$ & $166.3 \mathrm{e}-\mathrm{g}$ & $126.5 \mathrm{ij}$ & $163.4 \mathrm{BC}$ & $68.7 \mathrm{bc}$ & $60.7 \mathrm{~d}-\mathrm{f}$ & $50.6 \mathrm{gh}$ & $60.0 \mathrm{~B}$ \\
\hline MeJA $2.0 \mathrm{mM}$ & $213.2 \mathrm{a}$ & $188.4 \mathrm{~cd}$ & 151.2gh & $184.3 \mathrm{~A}$ & 79.5 a & $64.8 \mathrm{~cd}$ & $53.8 \mathrm{f}-\mathrm{g}$ & $66.0 \mathrm{~A}$ \\
\hline Chitosan $0.5 \%$ & $193.8 \mathrm{~b}-\mathrm{d}$ & $156.5 \mathrm{f}-\mathrm{g}$ & $120.4 \mathrm{jk}$ & $156.9 \mathrm{C}$ & 70.9 bc & 58.3 ef & $47.2 \mathrm{hi}$ & $58.8 \mathrm{~B}$ \\
\hline Chitosan $1.0 \%$ & $207.8 a b$ & 171.4 ef & $139.0 \mathrm{hi}$ & $172.7 \mathrm{~B}$ & 81.7 a & $66.9 \mathrm{~cd}$ & $56.5 \mathrm{e}-\mathrm{g}$ & $68.4 \mathrm{~A}$ \\
\hline Untreated & $174.2 \mathrm{~d}-\mathrm{f}$ & $140.5 \mathrm{hi}$ & $105.7 \mathrm{k}$ & $140.1 \mathrm{D}$ & $63.1 \mathrm{c}-\mathrm{e}$ & $52.4 \mathrm{f}-\mathrm{g}$ & $41.7 \mathrm{i}$ & $52.4 \mathrm{C}$ \\
\hline Control & $203.1 \mathrm{a}-\mathrm{c}$ & $178.6 \mathrm{de}$ & $159.2 \mathrm{fg}$ & $180.3 \mathrm{~A}$ & $76.9 \mathrm{ab}$ & $63.4 \mathrm{c}-\mathrm{e}$ & $55.9 \mathrm{e}-\mathrm{g}$ & $65.5 \mathrm{~A}$ \\
\hline Mean & $198.3 \mathrm{~A}$ & $167.0 \mathrm{~B}$ & $133.5 \mathrm{~B}$ & & $73.5 \mathrm{~A}$ & $61.1 \mathrm{~B}$ & $51.0 \mathrm{C}$ & \\
\hline
\end{tabular}

- Means having the same letter (s) in a column or line are not significantly different at $5 \%$ level

Table 8. Effect of methyl jasmonate and chitosan application on leaf zine and cupper content (ppm) of "Anna" apple seedlings grown under water and heat stresses conditions during 2018 and 2019 seasons.

\begin{tabular}{|c|c|c|c|c|c|c|c|c|}
\hline \multirow{3}{*}{ Treatments } & \multicolumn{4}{|c|}{ Zn (ppm) } & \multicolumn{4}{|c|}{$\mathrm{Cu}$ (ppm) } \\
\hline & \multicolumn{3}{|c|}{ Recommended water regiem } & \multirow{2}{*}{ Mean } & \multicolumn{3}{|c|}{ Recommended water regiem } & \multirow{2}{*}{ Mean } \\
\hline & $100 \%$ & $80 \%$ & $60 \%$ & & $100 \%$ & $80 \%$ & $60 \%$ & \\
\hline \multicolumn{9}{|c|}{ First Season } \\
\hline MeJA $1.0 \mathrm{mM}$ & $45.0 \mathrm{bc}$ & 36.4 ef & $30.9 \mathrm{gh}$ & $37.4 \mathrm{~B}$ & $9.32 \mathrm{bc}$ & 7.33 ef & $5.65 \mathrm{hi}$ & $7.43 \mathrm{~B}$ \\
\hline MeJA $2.0 \mathrm{mM}$ & $47.2 \mathrm{ab}$ & 39.3 de & $34.8 \mathrm{fg}$ & $40.4 \mathrm{~A}$ & $10.65 \mathrm{a}$ & $8.47 \mathrm{~cd}$ & $6.00 \mathrm{hi}$ & $8.37 \mathrm{~A}$ \\
\hline Chitosan $0.5 \%$ & $42.9 \mathrm{~cd}$ & $34.7 \mathrm{fg}$ & $29.2 \mathrm{~h}$ & $35.6 \mathrm{~B}$ & $9.11 \mathrm{~b}-\mathrm{d}$ & 7.76 ef & $5.17 \mathrm{ij}$ & $7.18 \mathrm{~B}$ \\
\hline Chitosan $1.0 \%$ & $50.3 \mathrm{a}$ & $41.8 \mathrm{~cd}$ & $32.7 \mathrm{f}-\mathrm{h}$ & $41.6 \mathrm{~A}$ & $9.53 \mathrm{a}-\mathrm{c}$ & 7.83 ef & $5.33 \mathrm{~h}-\mathrm{j}$ & $7.56 \mathrm{~B}$ \\
\hline Untreated & 38.7 de & $31.7 \mathrm{gh}$ & $25.0 \mathrm{i}$ & $31.8 \mathrm{C}$ & 7.74 ef & $6.52 \mathrm{gh}$ & $4.26 \mathrm{j}$ & $6.17 \mathrm{C}$ \\
\hline Control & $48.9 \mathrm{a}$ & $40.5 \mathrm{~d}$ & 35.6 ef & $41.7 \mathrm{~A}$ & $10.24 a b$ & $8.11 \mathrm{~d}-\mathrm{f}$ & $6.15 \mathrm{~g}-\mathrm{i}$ & $8.17 \mathrm{~A}$ \\
\hline Mean & $45.5 \mathrm{~A}$ & $37.4 \mathrm{~B}$ & $31.5 \mathrm{C}$ & & $9.30 \mathrm{~A}$ & $7.57 \mathrm{~B}$ & $5.53 \mathrm{C}$ & \\
\hline \multicolumn{9}{|c|}{ Second Season } \\
\hline MeJA $1.0 \mathrm{mM}$ & $50.0 \mathrm{~b}$ & $44.1 \mathrm{de}$ & $35.4 \mathrm{gh}$ & $43.2 \mathrm{C}$ & $11.29 a b$ & $9.06 \mathrm{~cd}$ & $7.11 \mathrm{f}$ & $9.15 \mathrm{~B}$ \\
\hline MeJA $2.0 \mathrm{mM}$ & $55.3 \mathrm{a}$ & $48.3 \mathrm{bc}$ & 40.5 ef & $48.0 \mathrm{~A}$ & $12.11 \mathrm{a}$ & $9.77 \mathrm{~cd}$ & 7.82 ef & $9.90 \mathrm{~A}$ \\
\hline Chitosan $0.5 \%$ & $48.6 \mathrm{bc}$ & 41.2 ef & $33.6 \mathrm{~h}$ & $41.1 \mathrm{C}$ & 10.22 bc & $8.53 \mathrm{de}$ & $6.84 \mathrm{fg}$ & $8.53 \mathrm{C}$ \\
\hline Chitosan $1.0 \%$ & $56.9 \mathrm{a}$ & $45.1 \mathrm{~cd}$ & $36.9 \mathrm{gh}$ & $46.3 \mathrm{AB}$ & $10.86 b$ & $8.92 \mathrm{de}$ & $7.35 \mathrm{f}$ & $9.04 \mathrm{BC}$ \\
\hline Untreated & $43.8 \mathrm{de}$ & $38.5 \mathrm{fg}$ & $28.2 \mathrm{i}$ & $36.8 \mathrm{D}$ & $9.67 \mathrm{~cd}$ & $7.43 \mathrm{f}$ & $5.72 \mathrm{~g}$ & $7.61 \mathrm{D}$ \\
\hline Control & $54.1 \mathrm{a}$ & $46.3 b-d$ & $37.3 \mathrm{f}-\mathrm{h}$ & $45.9 \mathrm{~B}$ & $12.02 \mathrm{a}$ & $9.28 \mathrm{~cd}$ & 7.91 ef & $9.74 \mathrm{~A}$ \\
\hline Mean & $51.2 \mathrm{~A}$ & $43.9 \mathrm{~B}$ & $35.7 \mathrm{C}$ & & $11.03 \mathrm{~A}$ & $8.83 \mathrm{~B}$ & $7.13 \mathrm{C}$ & \\
\hline
\end{tabular}

- Means having the same letter (s) in a column or line are not significantly different at $5 \%$ level 


\subsection{Chemical constituents}

\subsubsection{Total Carbohydrates (\%)}

It is clear from data in Table 9 that, total carbohydrates (\%) clearly affected with methyl jasmonate and chitosan treatments as well as anti-stress materials than untreated ones in both studied seasons. Heights values of total carbohydrates (33.10 and $37.70 \%$ ) were obtained with methyl jasmonate at $2.0 \mathrm{mM}$ in the two studied seasons respectively. However, the chitosan treatments at $1.0 \%$ increased the accumulation of carbohydrates percentage slightly lower in the control plants (did not expos to heat stress) in first season of study.

In general, the percentage of total carbohydrates in apple seedling decreased gradually with increasing water stress levels. However, irrigation with $100 \%$ of supplementary water regiem showed the maximum values (35.64 and $40.33 \%$ ) of carbohydrates, while irrigation with $60 \%$ gave the lowest values (22.85 and $27.29 \%$ ) during the two seasons regardless of the used treatments. Interaction values showed that the plants irrigation with $100 \%$ of supplementary water regiem and sprayed with high concentrations of methyl jasmonate or chitosan showed slightly higher values of total carbohydrates was superior without significant differences with the control (plants not exposed to any stress).

In this respect, Lisar et al (2012) confirmed that, carbohydrates accumulation became reduced parallel with degree of water deficit, possibly because of plant under drought stress became tended to hold soluble sugars than convert to carbohydrates likely attributed to her position in osmotic adjustment. Moreover, the decrease of potassium level under stresses leads to a decrease in the metabolism of carbohydrates, as it plays an important role in the transport of sugars and the formation of starch and carbohydrates. However, Mohamed and Tanany (2016) counseled that stressed plant is not able to supply, energy needed to convert sugars to carbohydrates. Finally, the received findings agreed with EL-Tanahy et al (2012), who indicated that total carbohydrates significantly increased with chitosan spraying at high concentration in compare with low dose or water spray. Fu et al (2017) quote that, both drought stress or water deficit impact on reducing turgor pressure, rising ion toxicity and inhibiting photosynthesis. Several researches cleared that the increase in the endogenous methyl jasmonate content substance became speedy after drought stress. However with prolongation of the stress it reduced to the basal degree. Also, Qiu et al (2014) determined that the use of methyl jasmonate resulted in an increase carbohydrates, sugars, total soluble sugar, free amino acids, protein contents, and antioxidant enzymes.

\subsubsection{Total chlorophyll (mg/100g F.wt)}

Data in Table 9 showed an evident effect to both studied factors on total chlorophyll of "Anna" apple seedlings. The plants exposure only to heat stress without water stress (100\% recommended water) exhibited the higher significant values of total chlorophyll in both studied seasons, compared to those plants subjected to water stress ( 80 or $60 \%$ ). The highest total chlorophyll (1.55 and $1.67 \mathrm{mg} / 100 \mathrm{~g}$ Leaves F.wt) were obtained with $2.0 \mathrm{mM}$ methyl jasmonate in first and second seasons, respectively, followed by the treatment chitosan at $1.0 \%$ which was similar to the control plants. However, the other treatments recorded less value than these in the mentioned treatments with significant differences between them. The highest interaction values of total chlorophyll were achieved by plants treated by $2.0 \mathrm{mM}$ methyl jasmonate irrigated with different water regiem levels than other anti-stresses treatments or untreated plant in the same stress condition.

Mohamed et al (2018) reported that, chitosan application mitigate, water stress thought impact on photosynthetic pigments and increment chlorophyll content through increasing cytokines level which stimulate chlorophyll synthesis. Beside found that, extremely increased in each $\mathrm{N}$ and $\mathrm{K}$ level in plant shoots applied with chitosan that can be play an essential role in increasing chloroplasts number per cell and raised the level of chlorophyll synthesis. 
Table 9. Effect of methyl jasmonate and chitosan application on total carbohydrates (\%) and total chlorophyll (mg/g leaves F.wt) of Anna apple seedlings grown under water and heat stresses conditions during 2018 and 2019 seasons

\begin{tabular}{|c|c|c|c|c|c|c|c|c|}
\hline \multirow{3}{*}{ Treatments } & \multicolumn{4}{|c|}{$\begin{array}{c}\text { Total Carbohydrates } \\
(\%)\end{array}$} & \multicolumn{4}{|c|}{$\begin{array}{l}\text { Total chlorophyll } \\
\text { (mg/100g F.wt) }\end{array}$} \\
\hline & \multicolumn{3}{|c|}{ Recommended water regiem } & \multirow{2}{*}{ Mean } & \multicolumn{3}{|c|}{ Recommended water regiem } & \multirow{2}{*}{ Mean } \\
\hline & $100 \%$ & $80 \%$ & $60 \%$ & & $100 \%$ & $80 \%$ & $60 \%$ & \\
\hline \multicolumn{9}{|c|}{ First Season } \\
\hline MeJA $1.0 \mathrm{mM}$ & $33.85 \mathrm{~cd}$ & 29.11 ef & $21.75 \mathrm{~h}$ & $28.24 \mathrm{C}$ & $1.71 \mathrm{ab}$ & $1.41 \mathrm{de}$ & $1.11 \mathrm{gh}$ & $1.41 \mathrm{BC}$ \\
\hline MeJA $2.0 \mathrm{mM}$ & $39.75 \mathrm{a}$ & $33.00 \mathrm{~cd}$ & $26.55 \mathrm{fg}$ & $33.10 \mathrm{~A}$ & $1.86 \mathrm{a}$ & $1.52 \mathrm{~cd}$ & $1.27 \mathrm{e}-\mathrm{g}$ & $1.55 \mathrm{~A}$ \\
\hline Chitosan $0.5 \%$ & $35.42 \mathrm{bc}$ & 28.14 ef & $22.13 \mathrm{~h}$ & $28.56 \mathrm{C}$ & $1.64 \mathrm{bc}$ & $1.34 \mathrm{~d}-\mathrm{f}$ & $0.980 \mathrm{hi}$ & $1.32 \mathrm{C}$ \\
\hline Chitosan $1.0 \%$ & $36.26 \mathrm{a}-\mathrm{c}$ & $33.83 \mathrm{~cd}$ & $24.14 \mathrm{gh}$ & $30.41 \mathrm{~B}$ & $1.75 a b$ & $1.37 \mathrm{de}$ & $1.18 \mathrm{fg}$ & $1.43 \mathrm{~B}$ \\
\hline Untreated & $30.11 \mathrm{de}$ & $24.46 \mathrm{gh}$ & $17.31 \mathrm{i}$ & $23.96 \mathrm{D}$ & $1.44 \mathrm{~cd}$ & $1.16 \mathrm{f}-\mathrm{h}$ & $0.815 \mathrm{i}$ & $1.14 \mathrm{D}$ \\
\hline Control & $38.45 a b$ & $32.60 \mathrm{~cd}$ & $25.24 \mathrm{fg}$ & $32.10 \mathrm{~A}$ & $1.78 a b$ & $1.45 \mathrm{~cd}$ & $1.23 \mathrm{e}-\mathrm{g}$ & $1.49 \mathrm{AB}$ \\
\hline Mean & $35.64 \mathrm{~A}$ & $29.32 \mathrm{~B}$ & $22.85 \mathrm{C}$ & & $1.70 \mathrm{~A}$ & $1.38 \mathrm{~B}$ & $1.10 \mathrm{C}$ & \\
\hline \multicolumn{9}{|c|}{ Second Season } \\
\hline MeJA $1.0 \mathrm{mM}$ & $37.60 \mathrm{bc}$ & $34.26 \mathrm{~cd}$ & $26.92 \mathrm{~h}$ & $32.93 \mathrm{BC}$ & $1.75 \mathrm{bc}$ & $1.52 \mathrm{de}$ & $1.17 \mathrm{gh}$ & $1.48 \mathrm{BC}$ \\
\hline MeJA $2.0 \mathrm{mM}$ & $45.13 \mathrm{a}$ & $37.52 \mathrm{bc}$ & $30.44 d-g$ & $37.70 \mathrm{~A}$ & $1.91 \mathrm{ab}$ & $1.66 \mathrm{~cd}$ & 1.43 ef & $1.67 \mathrm{~A}$ \\
\hline Chitosan $0.5 \%$ & $38.53 b$ & $31.64 \mathrm{de}$ & $27.25 \mathrm{gh}$ & $32.47 \mathrm{C}$ & $1.72 \mathrm{bc}$ & $1.46 \mathrm{e}$ & $1.05 \mathrm{gh}$ & $1.41 \mathrm{C}$ \\
\hline Chitosan $1.0 \%$ & $42.54 \mathrm{a}$ & $33.75 \mathrm{~cd}$ & $27.71 \mathrm{e}-\mathrm{h}$ & $34.67 \mathrm{~B}$ & $1.83 a b$ & $1.51 \mathrm{de}$ & $1.25 f$ & $1.53 \mathrm{~B}$ \\
\hline Untreated & $34.25 \mathrm{~cd}$ & $28.71 \mathrm{e}-\mathrm{h}$ & $22.15 \mathrm{i}$ & $28.37 \mathrm{D}$ & $1.70 \mathrm{~b}-\mathrm{d}$ & $1.22 \mathrm{fg}$ & $0.921 \mathrm{~h}$ & $1.28 \mathrm{D}$ \\
\hline Control & $43.93 \mathrm{a}$ & $36.16 \mathrm{bc}$ & $29.26 e-h$ & $36.45 \mathrm{~A}$ & $1.97 \mathrm{a}$ & $1.58 \mathrm{c}-\mathrm{e}$ & 1.39 ef & $1.65 \mathrm{~A}$ \\
\hline Mean & $40.33 \mathrm{~A}$ & $33.67 \mathrm{~B}$ & $27.29 \mathrm{C}$ & & $1.81 \mathrm{~A}$ & $1.49 \mathrm{~B}$ & $1.20 \mathrm{C}$ & \\
\hline
\end{tabular}

Means having the same letter (s) in a column or line are not significantly different at $5 \%$ level

\subsection{Physiological attributes}

\subsubsection{Proline amino acid content $(\mu \mathrm{g} / \mathrm{g}$ dry weight)}

It is evident from data in Table $\mathbf{1 0}$ that proline contents were significantly increased with increasing water stress levels. Un-stressed irrigated water plants recorded $(70.6 \& 62.1 \mu \mathrm{g}$ proline/g d.wt) compared to $(136.0 \& 118.6 \mu \mathrm{g}$ proline/g d.wt) for $60 \%$ water stress in both seasons. All the applied treatments were effective in reducing proline amino acid levels than those in the untreated ones. Minimum values of proline amino acid contents were recorded in plants treated with $2.0 \mathrm{mM}$ methyl jasmonate whereas, maximum values were observed with untreated plants. Interaction values showed that, the least values of proline were recorded by apple seedlings treated with $2.0 \mathrm{mM}$ MeJA, under $100 \%$ recommended water regiem .It is worth that, all apple seedlings treated with MeJA at $2.0 \mathrm{mM}$ are similar to the control in giving the lowest values of proline values under all water regiems levels. In the contrast, the highest interaction values of proline amino acid obtained with the low concentrations of anti - stress materials (1.0 mM methyl jasmonate and $0.5 \%$ chitosan) as well as untreated apple seedlings under different stresses conditions for both seasons.

In this regard, Ashraf and Foulad (2007) Stated that, proline is considered an essential amino acid in plants, which safeguard plants from different stresses and assists getting from stress very speedily. Large quantities of compatible low-molecularweight solvents and highly soluble organic compounds accumulate and are usually non-toxic at high cellular concentrations. These dissolves protect plants from stress by contributing to cellular osmotic modification, detoxification, membrane protection and enzyme / protein fixation. In general, Hayat et al (2012) extracted that, proline accumulation in plant tissues is a sign for biotic and abiotic stresses. Basically, proline is an osmotic substance appropriate, with cytoplasm and highly soluble in water. Therefore, high accumulation of proline through water stress helps plants maintain a higher internal water content by affecting osmotic capacity, which is a factor of water potential, leading to improved resilience to drought. 


\section{Application of methyl jasmonate and chitosan on behavior of "Anna" apple seedlings grown under water and heat stress conditions}

\subsubsection{Glycine betaine content $(\mu \mathrm{g} / \mathrm{g}$ d.wt)}

At it shown in Table 10, Anna apple seedlings irrigated with $100 \%$ of recommended water regiem produced lower glycine betaine values than those irrigated with 80 or $60 \%$ of recommended water regiem in the two studied seasons.

The values of glycine betaine under stress conditions generally ranged from (23.1 to $40.3 \mu \mathrm{g} / \mathrm{g}$ d.wt) and these are generally lower than the accumulated proline values in the same conditions, which ranged from (62.1 to $136.0 \mu \mathrm{g} / \mathrm{g}$ Leaves d.wt). The mechanisms of Glycine betaine biosynthesis affected by all used treatments, except the treatment of $2.0 \mathrm{mM}$ MeJA where it was superior than others in both studied seasons, followed by the treatment of chitosan at $1.0 \%$ with significant differences between them.

The maximum interaction values showed that, the accumulation of glycine betaine was observed with untreated seedlings under the three irrigation water stresses conditions which exhibited a gradual increase, the level glycine betaine reached to 30.1 , 37.4 and $45.0 \mu \mathrm{g} / \mathrm{g}$ d.wt in the first season and (32.7, 39.2 and $48.0 \mu \mathrm{g} / \mathrm{g} \mathrm{d}$.wt) in the second season. On the contrast, the treatment of $2.0 \mathrm{mM} \mathrm{MeJA}$ under heat and water stress levels was effective in reducing glycine betaine values which is similar to the apple seedling did not expose to stresses.

Glycine betaine is classified as an osmolite that affects osmotic adaptation and helps protect plants under stress conditions. It protects the photosynthesis mechanism and acts as a stabilizer for enzymes (Rezaei et al 2012). Additionally, Wei et al (2017) stated that glycine betaine maintains a higher photosynthetic rate, thus increasing the production and transmission of sucrose to enhance plant response to low phosphate stress.

Also, Li et al (2017) stated that, chitosan application enhanced the production of metabolites and amino acids for example proline, aspartic acid, valine and serine. The impact of chitosan on plant species may follow different mechanisms. Membrane integrity is oftentimes disturbed when the plant is subjected of water stress However, chitosan plays as a positive regulator in osmotic adaptation and minimizing the adverse effect of drought stress symptoms (Bistgani et al 2017).

\subsubsection{Phenolic compounds (mg / 100 g F.wt.)}

Data in Table 10 show the effect of water and heat stresses, MeJA and Chitosan and their interactions on phenolic compounds (mg / $100 \mathrm{~g}$ F.wt.) of Anna apple seedlings. The higher values of phenolic compounds were recorded with apple seedlings irrigated with $60 \%$ of water regiem in both studied seasons. However, all applied anti-stress materials were effective in decreasing the values of phenolic compounds compared to untreated ones. The treatments of $2.0 \mathrm{mM}$ MeJA $(0.725 \& 685 \mathrm{mg} /$ $100 \mathrm{~g} \mathrm{F.wt}$ ) as well as $1.0 \%$ Chitosan (0.768 \& $0.753 \mathrm{mg} / 100 \mathrm{~g} \mathrm{F.wt}$ ) were more pronounced as anti-stresses material in this respect, which is equal to plants that have not been stressed (control $0.737 \& 0.709 \mathrm{mg} / 100 \mathrm{~g}$ F.wt) during first and second season respectively. The lowest interaction values of phenolic compounds were observed by apple seedlings sprayed with the $2.0 \mathrm{mM}$ MeJA \& $1.0 \%$ Chitosan and irrigated with all levels of recommended water regiem against contradict trend with untreated apple seedlings which disclose the highest value.

Phenolic compounds playes many roles in plants physiology suchas the plant growth and development, consisting seed germination, biomass accumulation, and improvement plant metabolism (Naikoo et al 2019). In reaction to abiotic stresses, polyphenols are commonly elevated in plants, phenolics confer actually higher tolerance to plants against various stress condition such as heavy metals, salinity, drought, and temperature (Wang et al 2019). Plants growing under stress conditions have the potential to produce more phenolic compounds than those grown under normal conditions (Ancillotti et al 2015). Biosynthesis of phenolic compounds under stress is influenced by the change activities of various key enzymes (Smirnov et al 2015). Chitosan is called acquainted elicitor to sign specific molecules that could act as a stress messenger to result suitable reaction to stressful conditions (Bistgani et al 2017).

Anjum et al (2011) pronounced that application of methyl jasmonate enhanced the proline contents and it assisted to maintain relative water content in water stressed plants than the control. Jasmonic acid regulate stomata opening and closing to reduce water loss (Savchenko et al 2014). Foliar application of methyl jasmonate to plants increased concentration of sugars, flavonoids and phenolic compounds to enhance water stress resistance ability (Mohamed and Latif 2017). 


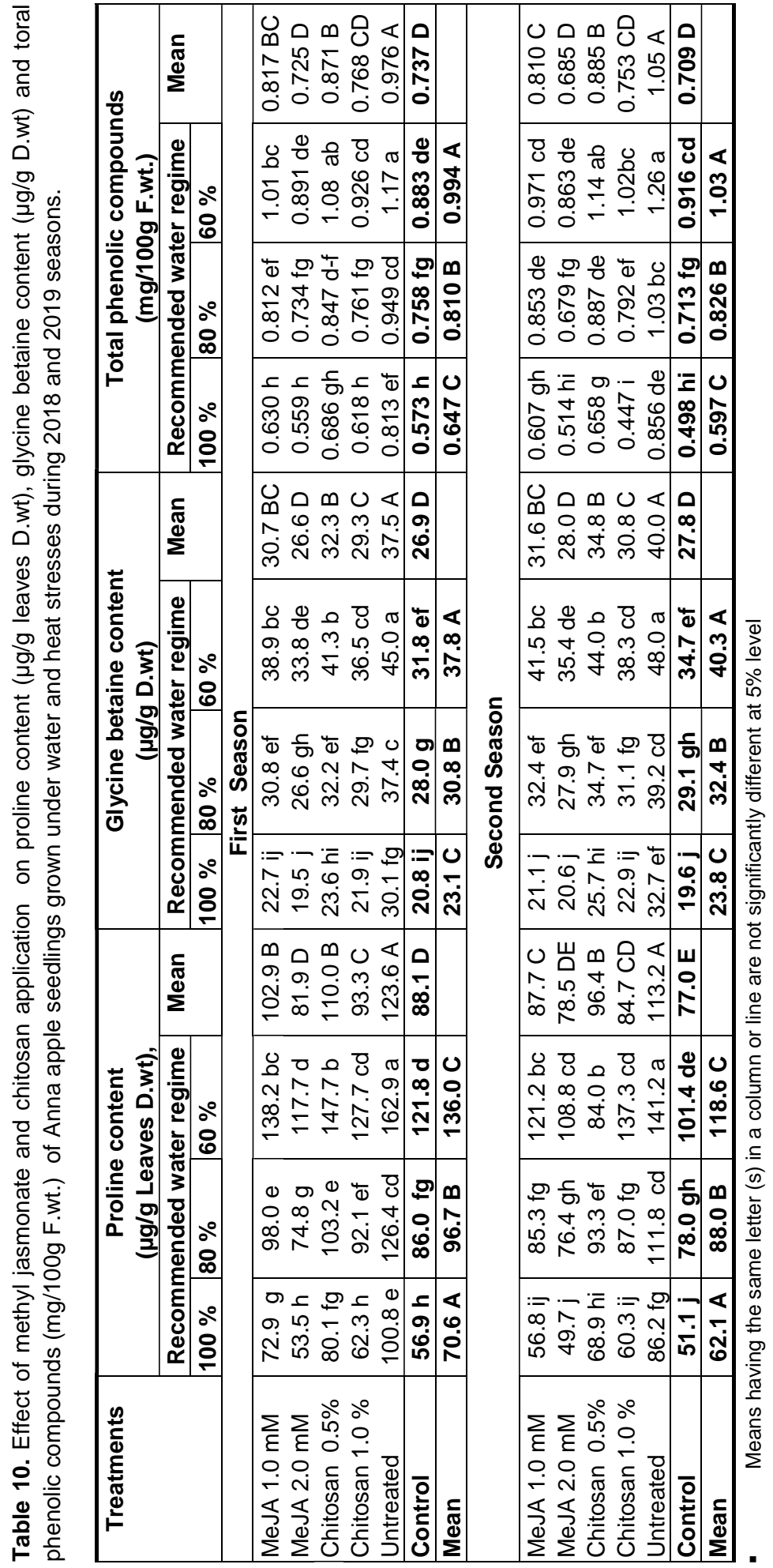




\section{Application of methyl jasmonate and chitosan on behavior of "Anna" apple seedlings grown under water and heat stress conditions}

\section{References}

Ancillotti, C; Bogani, P; Biricolti, S; Calistri, E; Checchini, L; Ciofi, L; Gonnelli, C; Del Bubba, M (2015) Changes in polyphenol and sugar concentrations in wild type and genetically modified Nicotiana langsdor_i Weinmann in response to water and heat stress. Plant Physiol Biochem 97, 52-61.

Anjum, SA; Wang, L; Farooq, M; Khan, I; Xue, L (2011) Methyl jasmonate-induced alteration in lipid peroxidation, antioxidative defence system and yield in soybean under drought. J Agron Crop Sci 197, 296-301.

Ashraf, M; Foolad, MR (2007) Roles of glycine betaine and proline in improving plant abiotic stress resistance. Environ Exp Bot 59, 206-216.

Bates, LS; Waldren, RP; Teare, ID (1973) Rapid determination of free proline for water stress studies. Plant Soil 39, 205-207.

Bistgani, ZE; Siadat, SA; Bakhshandeh, A; Pirbalouti, AG; Hashemi, M (2017) Interactive effects of drought stress and chitosan application on physiological characteristics and essential oil yield of Thymus daenensis Celak. Crop J 5, 407-415.

Bittelli, M; Flury, M; Campbell, GS; Nichols, EJ (2001) Reduction of transpiration through foliar application of chitosan. Agric for Meteorol 107, 167 175.

Bllinger, Y; Lahrer, F (1987) Proline accumulation in higher plants: a redox buffer. Plant Physiol 6, 23-27.

Boyer, JS (1982) Plant productivity and environment. Sci New Series 218, 443-448.

Bringham, FT (1982) Methods of Soil Analysis, (Ed), Part 2, Agronomy 9 431-447.

Budak, H; Kantar, M; Kurtoglu, KY (2013) Drought Tolerance in Modern and Wild Wheat. Sci Worl J Review Article $16 \mathrm{p}$.

Camilo, EM; Aguilar-Caamal, LF; Echevarría-Machado, I; Medina-Lara, F; Cach, LS; MartínezEstévez, M (2019) Contribution of Glycine Betaine and Proline to Water Deficit Tolerance in Pepper Plants Hort Sci 54, 1044-1054.

Campos, ML; Kang, JH; Howe, GA (2014) Jasmonate-triggered plant immunity. J Chem Ecol 40, 657-675.

Chaitanya, KV; Sundar, DA (2001) Ramachandra Reddy, Mulberry leaf metabolism under high temperature stress, Biologia Plant 44, 379-384.
Chapman, HD; Pratt, PR (1982) Analysis for Soils, Plants, and Waters. Pub- Search 69, 237-277.

Cheong, JJ; Choi, YD (2003) Methyl jasmonate as a vital substance in plants. Trends Genet 19, 409413.

El-Bassiony, AM; Fawzy, ZF; El-Nemr, MA; Li Yunsheng (2014) Improvement of growth, yield and quality of two varieties of kohlrabi plants as affected by application of some biostimulants. Middle East $J$ of Agriculture Research 3, 491-498.

El-Miniawy, SM; Ragab, ME; Youssef, SM; Metwally, AA (2013) Response of strawberry plants to foliar spraying of chitosan. Res J Agric Biol Sci 9, 366-372.

El-Tanahy, AMM; Mahmoud, AR; Abde-Mouty, MM; Ali, $\mathrm{AH}$ (2012) Effect of chitos and oses and nitrogen sources on the growth, yield and seed quality of cowpea. Aus J Basic Appl Sci 6, 115-121.

Fang, Y; Xiong, L (2015) General mechanisms of drought response and their application in drought resistance improvement in plants. Cell Mol Life Sci 72, 673-689.

Farouk, S; Ramadan, AA (2012) 'Improving growth and yield of cowpea by foliar application of chitosan under water stress'. Egyptian J of Biology 14, 14-26.

Fereres, E; Evans, RG (2006). Irrigation of fruit trees and vines: an introduction. Irrig Sci 24, 55-56.

Fu, J; Wu, H; Ma, S; Xiang, D; Liu, R; Xiong, L (2017) Attenuates drought resistance by regulating $\mathrm{JA}$ and ABA signaling in rice. Front Plant Sci 8, 113.

Guan, YJ; Hu, J; Wang, X; Shao, C (2009) Seed priming with chitosan improves maize germination and seedling growth in relation to physiological changes under low temperature stress. J Zhejiang Univ Sci 10, 427-433.

Gupta, A; Hisano, H; Hojo, Y; Matsuura, T; Ikeda, Y; Mori, IC; Kumar, MS (2017) Global profiling of phytohormone dynamics during combined drought and pathogen stress in Arabidopsis thaliana reveals ABA and JA as major regulators. Sci Rep-UK 7, 4017.

Havaux, I (1993) Rapid photosynthetic adaptation to heat stress triggered in potato leaves by moderately elevated temperatures. Plant Cell Environ 16, 461467. 
Hayat, SO; Alyemeni, MN; Wani, AS; Pichtel, J; Ahmad, A (2012) Role of proline under changing environments: A Review Plant Signal Behav 17, 1456-1466.

Huber, DPW; Philippe, RN; Madilao, LL; Sturrock, $\mathrm{RN}$; Bohlmann, J (2005) Changes in anatomy and terpene chemistry in roots of Douglas-fir seedlings following treatment with methyl jasmonate. Tree Physiol 25, 1075-1083.

IPCC. (2001) Third assessment report-Climate change.

Itoh, T; Hibi, T; Fujii, Y; Sugimoto, I; Fujiwara, A; Suzuki, F (2013) Cooperative degradation of chitin by extracellular and cell surface-expressed chitinases from Paenibacillus sp. strain FPU-7. Applied and Environmental Microbiology 79, 7482-7490.

Jackson, ML (1973) Soil Chemical Analysis Prentice Hall of India Private, LTD, New Delhi.

Jury, WA; Vaux, HJ (2007) The emerging global water crisis: managing scarcity and conflict between water users. Adv Agron 95, 1-76.

Khan, WM; Prithiviraj, B; Smiyh, DL (2002) Effect of foliar application of chitinoligosaccharides on photosynthesis of maize and soybean. Photosynthetica 40, 621-624.

Levitt, J (1980) Responses of Plants to Environmental Stresses, Academic Press, New York, USA I, $347-470$

Li, Z; Zhang, Y; Zhang, X; Merewitz, E; Peng, Y; Ma, X; Yan, Y (2017) Metabolic pathways regulated by chitosan contributing to drought resistance in white clover. J Proteome Res 16, 3039-3052.

Lisar, SY; Motafakkerazad, R; Hossain, MM; Rahman, MM (2012) Water Stressin Plants: Causes, effects and responses. In Tech pp 1-14.

Mafakheri, A; Siosemardeh, A; Bahramnejad, B; Struik, PC; Sohrabi, Y (2010) 'Effect of drought stress on yield, proline and chlorophyll contents in three chickpea cultivars'. Australian $J$ of Crop 4, 580-585.

Malekpoor, F; Pirbalout, AG; Salim, A (2016) Effect of foliar application of chitosan on morphological and physiological character is tics of basil under reduced irrigation. Res Crops 17, 354-359.

Malerba, M; Cerana, R (2015) Reactive oxygen and nitrogen species indefense/stress responses activated by chitosan in sycamore cultured cells. Int $J$ Mol Sci 16, 3019-3034.
Mikhael, GB; Mady, AA (2007) Effect of some drip irrigation and mulching treatments on: II. Yield, fruit quality and water use efficiency of "Anna" apple trees grown in new reclaimed soils. Minufiya $J$ Agric Res 32, 1175-1191.

Mohamed, HI; Latif, HH (2017) Improvement of drought tolerance of soybean plants by using methyl jasmonate. Physiol Mol Biol Plants 23, 545-556.

Mohamed, SA; El-Tanany, MM (2016) Efficacy of foliar applications of salicylic acid, zinc and potassium on reducing fruit drop, yield improvement and quality of Balady mandarins. Egypt $J$ Hort 43, 371388 .

Mohamed, Shaimaa A; Ahmed, HS; Amal A ElBaowab (2018) Effect of Chitosan, Putrescine and Irrigation Levels on the Drought Tolerance of Sour Orange Seedlings. Egypt J Hort 45, 257-273.

Monakhova, OF; Chernyader, LI (2002) 'Protective role of Kartolin-4 in wheat plants exposed to soil drought'. Applied Biochemistry Microbiology 38, 373-380.

Mondal, MMA; Malek, MA; Puteh, AB; Ismail, MR (2012) Foliar application of chitosan on growth and yield attributes in mung bean. Bangladesh J Bot 41, 179-183.

Moran, R; Porath, D (1985) Chlorophyll determination in intact tissues using N,N-351 dimethylformamide. Plant Physiology 65, 478-479.

Moreira, X; Zas, R; Sampedro, L (2012) Methyl Jasmonate as Chemical Elicitor of Induced Responses and Anti-Herbivory Resistance in Young Conifer Trees, in Me' Rillon, JM; Ramawat, KG (eds.): Plant Defence: Biological Control. Springer, Dordrecht, the Netherlands pp. 345-362.

Motallebi, P; Niknam, V; Ebrahimzadeh, H; Hashemi, M; Pisi, A; Prodi, A; Tonti, S; Nipoti, P (2015) Methyl jasmonate strengthens wheat plants against root and crown rot pathogen Fusarium culmorum infection. J Plant Growth Regul 34, 624-636.

Naikoo, MI; Dar, MI; Raghib, F; Jaleel, H; Ahmad, B; Raina, A; Khan, FA; Naushin, F (2019) Role and Regulation of Plants Phenolics in Abiotic Stress Tolerance: An Overview. In Plant Signaling Molecules; Elsevier: Amsterdam, the Netherlands, pp. 157-168.

Naz, N; Durrani, F; Shah, Z; Khan, NA (2018) Influence of heat stress on growth and physiological activities of potato (Solanum tuberosum L.). Phyton 87, 225-230. 


\section{Application of methyl jasmonate and chitosan on behavior of "Anna"}

apple seedlings grown under water and heat stress conditions

Postel, S (1998) Water for food production: will there be enough in 2025? Bio Sci 48, 629-637.

Qiu, Z; Guo, J; Zhu, A; Zhang, L; Zhang, M (2014) Exogenous jasmonic acid can enhance tolerance of wheat seedlings to salt stress. Ecotoxicol Environ Saf 104, 202-208.

Ravi Kumar, MN (2000) A review of chitin and chitosan applications. React Funct Polym 46, 1-27.

Rebbeca, B (2004) Soil Survey Laboratory Methods Manual", Soil Survey Investigation Report. 42 Natural Resources Conservation Services.

Rezaei, MA; Jokar, I; Ghorbanli, M; Kaviani B Kharabian; Masouleh, A (2012) Morpho-physiological improving effects of exogenous glycine betaine on tomato (Lycopersicum esculentum Mill.) cv. PS under drought stress conditions. Plant Omics 5, 7986.

Rinaudo, M (2006) Chitin and chitosan: properties and application. Prog Polym Sci 31, 603-632.

Rohwer, CL; Erwin, JE (2008) Horticultural applications of jasmonates: a review. J Hort Sci Biotechnol 83, 283-304.

Saif Eldeen, UM; Shokr, MM; El-Shotoury, RS (2014) Effect of foliar spray with seaweeds extract and chitosan on earliness and productivity of globe artichoke. J Plant Prod Mansoura Univ 5, 11971207.

Sakamoto, A; Murata, N (2002) The role of glycine betaine in the protection of plants from stress: clues from transgenic plants. Plant Cell Environment 25, 163-171.

Sakata, Y; Komatsu, K; Takezawa, D (2014) 'ABA as a universal plant hormone'. Progress in Botany 75, 57-96.

Saniewski, M; Horbowicz, M; Puchalski, J; Ueda, J (2003) Methyl jasmonate stimulates the formation and accumulation of anthocyanins in Kalanchoe blossfeldiana. Acta Physiol Plant 25, 143-149.

Savchenko, T; Kolla, VA; Wang, CQ; Nasafi, Z; Hicks, DR; Phadungchob, B; Chehab, WE; Brandizzi, F; Froehlich, J; Dehesh, K (2014) Functional convergence of oxylipin and abscisic acid pathways controls stomatal closure in response to drought. Plant Physiol 164, 1151-1160.

Sharif, R; Mujtaba, M; Ur Rahman, M; Shalmani, A; Ahmad, H; Anwar, T; Tianchan, D; Wang, X (2018) The multifunctional role of chitosan in horticultural crops. Molecules 23, 872.
Shehata, SA; Zakaria, FF; El-Ramady, HR (2012) Response of cucumber plants to foliar application of chitosan and yeast under greenhouse conditions. Aust J Basic and Appli Sci 6, 63-71.

Singleton, VL; Rossi, JA (1965) Colorimetry of total phenolics with phosphomolybdic-phosphotungstic acid reagents. Am J Enol Vitic 16, 144-158.

Slama, I; Ghnaya, T; Hessini, K; Messedi, D; Savoure, A; Abdelly, C (2007) 'Comparative study of the effects of mannitol and PEG osmatic stress on growth and solute accumulation in Sesuvium portulacastrum'. Environmental and Experimental Botany 61, 10-17.

Smirnov, OE; Kosyan, AM; Kosyk, OI; Taran, NY (2015) Response of phenolic metabolism induced by aluminium toxicity in Fagopyrum esculentum moench. Plants Ukr Biochem J, 87, 129-135.

Smith, MW; Kenworthy, AL; Bedford, OL (1979) The response of fruit trees to injection of nitrogen through a trickle irrigation system. J Amer Soc Hort Sci 104, 311-313.

Snedecor, GW; Cochran, GW (1990) Statistical Methods. 8th Ed The lowa State Univ., Press Ames, lowa. USA pp 503-507.

Soliman, MA; Ennab, HA; Mikhael, GB (2018) Effect of Periodic Deficit Irrigation at Different Fruit Growth Stages on Yield and Fruit Quality of "Anna" Apple Trees. J Plant Production, Mansoura Univ 9, 13-19.

Tsuchida, Y; Negoro, K; Hishiike, M (2011) Effect of initiation timing of drought stress on carbohydrate content and vegetative growth in Japanese apricot (Prunus mume Sieb. Et Zucc.) 'Nanko'. J Japan Soc Hort Sci 80, 19-25.

Verbruggen, N; Hermans, C (2008) Proline accumulation in plants: a review. Amino Acids 35, 753-759.

Wang, S; Liang, D; Li, C; Hao, Y; Ma, F; Shu, H (2012) Influence of drought stress on the cellular ultrastructure and antioxidant system in leaves of drought-tolerant and drought-sensitive apple rootstocks, Plant Physiology and Biochemistry 51, 8189.

Wang, J; Yuan, B; Huang, B (2019) Differential Heat-Induced Changes in Phenolic Acids Associated with Genotypic Variations in Heat Tolerance for Hard Fescue. Crop Sci 59, 667-674. 
Wasternack, C; Hause, B (2013) Jasmonates: Biosynthesis, perception, signal transduction and action in plant stress response, growth and development. An Update to the 2007 Review in Annals of Botany Ann Bot 111, 1021-1058.

Wei, D; Zhang, W; Wang, C; Meng, Q; Li, G; Chen, T; Yang, $X$ (2017) Genetic engineering of the biosynthesis of glycine betaine leads to alleviate salt-induced potassium efflux and enhances salt tolerance in tomato plants. Plant Sci 257, 74-83.
Wilde, SA; Cory, RB; Lyer, JG; Voigt, GK (1985) Soils and Plants Analysis for Tree Cultures. Ox for IBH, New Delhi, India pp. 94-105.

Young, SL; Yong, HK; Sung, BK (2005) Changes in the respiration, growth, and vitamin $C$ content of soybean sprouts in response to chitosan of different molecular weights. Hort Sci 40, 1333-1335. 


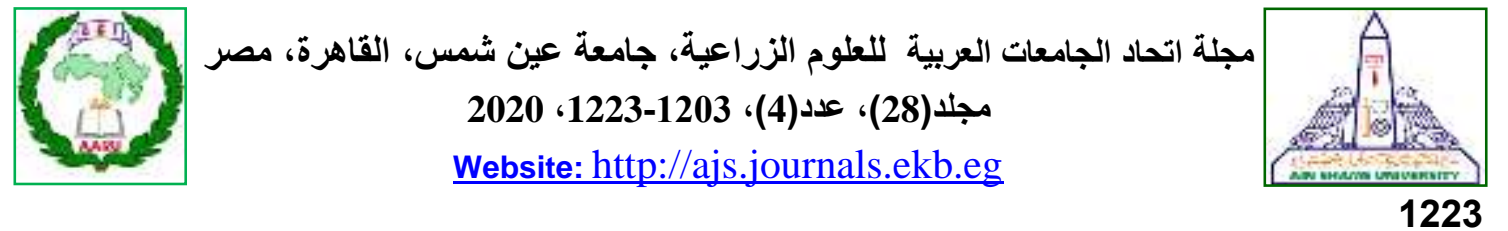

تأثير إستخدام ميثيل جاسيمونات والثيتوزان على سلوك شتلات التفاح "آنا" التي تنمو تحت ظروف الإجهاد المائي والحراري

$$
\begin{aligned}
& \text { سماح إبراهيم نصر 1" - غادة سليمان } 2 \\
& \text { 1- المعهد العالي للتعاون الزراعي - ص.ب. } 198 \text { حدائق شبرا - القاهرة - مصر لصر }
\end{aligned}
$$

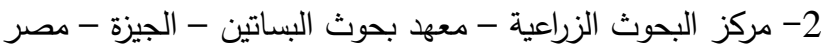

[86]

*Corresponding author: Samah55adel@yahoo.com

Received 14 October, 2020

Accepted 4 November, 2020

سجلت اعلي نمو خضرى خلال موسمي الدراسة. أثرت

كل المواد المضادة للاجهاد في زيادة مستوي شتلات التات

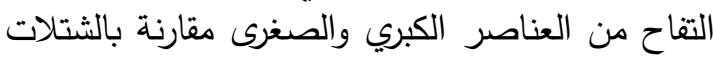

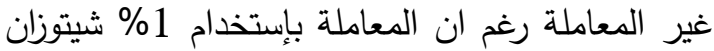
مع كل مستويات الري أدى الي تحسين الحالة الغدائية الدئية

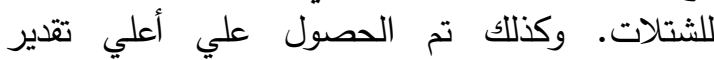

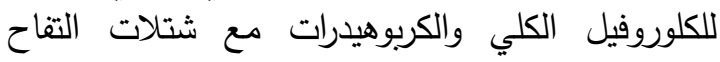

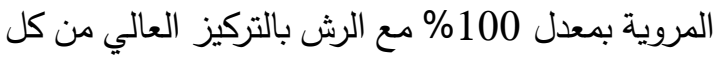

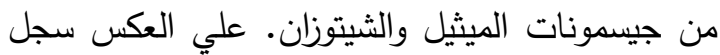

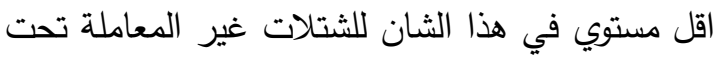
كل مستويات الري. أثرت المعاملة 2 ميمول جيسمونات الميتات المعات الميثيل و 1\% الثيتوزان تحت كل من الإجهاد المائي والحراري في تقليل مستوي حمض البرولين والجليسين تين

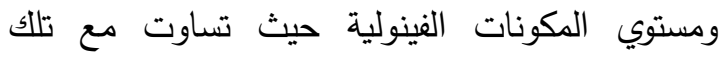

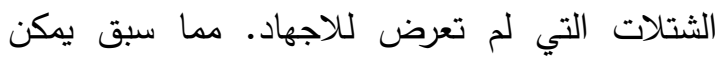

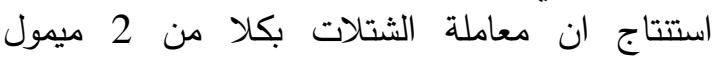
جيسمونات الميثيل و 1\% الثيتوزان مع كل مستويات

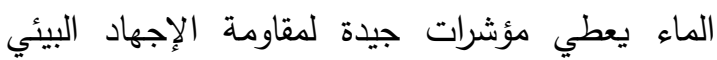
(المائي والحرارى).
تم تقييم إستخدام جيسمونات الميثيل والشيتوزان كمواد مضادة للإجهاد على شتلات تفاح الانا مزروعة تحت

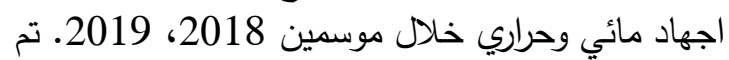
تعريض شتلات تفاح الأنا الى ثلاث مستوان مستويات من نظم

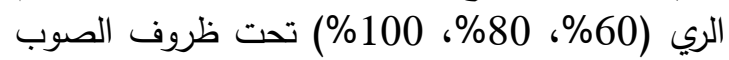
البلاستيكية عند درجة حرارة 45٪20 ثم عوملت بمستويين من جيسمونات الميثيل 1، 1، ميمول ومستورة الثيتوزان 5.5، 10.

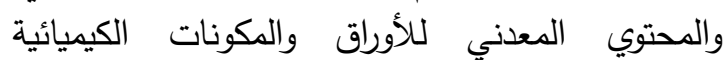
والصفات الفسيولوجية اثثاء تطور شتلات التفاح الانا

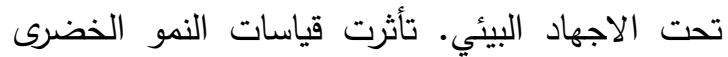

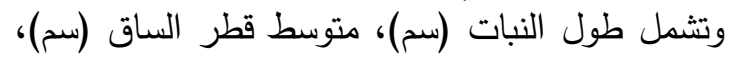

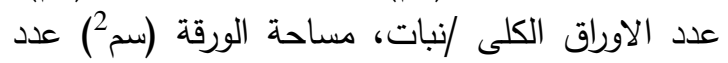

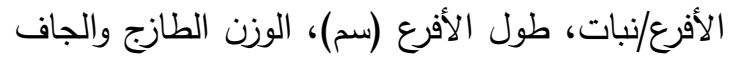

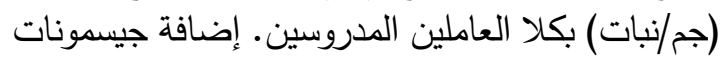

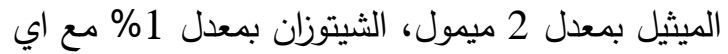

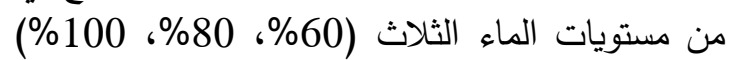
كان أفضل من باقي الاضافات او غير المعاملة حيث 